\begin{tabular}{|l|l|}
\hline $\begin{array}{l}\text { 2. To: (Receiving Organization) } \\
\text { Distribution }\end{array}$ & $\begin{array}{l}\text { 3. From: (Originating Organization) } \\
\text { 2F600/Facility Engineering }\end{array}$ \\
\hline $\begin{array}{l}\text { 5. Proj./Prog./Dept./Div.: } \\
\text { Piops Upgrade/SNF Project }\end{array}$ & $\begin{array}{l}\text { 6. Design Authority/Design Agent/Cog. Engr. } \\
\text { CC Kinkel }\end{array}$ \\
\hline
\end{tabular}

8. Originator Remarks:

Attached: Acceptance Test For KE ARMS

NA

7. Purchase Order No

NA

9. Equip./Component No:

NA

10. System/Bldg./Facility:

$05 / 105 \mathrm{KE} / 100 \mathrm{~K}$

12. Major Assm. Dwg. No.

11. Receiver Remarks:

11A. Design Baseline Document? $\bigcirc$ Yes $\bigcirc$ No

H-1-82604

13. Permit/Permit Application No.

NA

14. Required Response Date:

NA

\begin{tabular}{|l|l|}
\hline \multicolumn{2}{|l|}{15.} \\
\hline $\begin{array}{c}\text { (A) } \\
\text { Item } \\
\text { No. }\end{array}$ & (B) Document/Drawing No. \\
\hline 1 & HNE-3613 \\
\hline & \\
\hline & \\
\hline & \\
\hline & \\
\hline
\end{tabular}

DATA TRANSMITTED

16.

\begin{tabular}{l|l|l|}
$\begin{array}{l}\text { (C) Sheet } \\
\text { No. }\end{array}$ & (D) Rev. & (E) Title or Description of Data Transmitted \\
&
\end{tabular}

(F)

(G)

\begin{tabular}{c|c|c|c|}
$\begin{array}{c}\text { Approval } \\
\text { Desig- } \\
\text { nator }\end{array}$ & $\begin{array}{c}\text { Reason } \\
\text { for Trans- } \\
\text { mittal }\end{array}$ & $\begin{array}{c}\text { Origi- } \\
\text { nator } \\
\text { Dispo- } \\
\text { stion }\end{array}$ & $\begin{array}{c}\text { Receiv- } \\
\text { er } \\
\text { Dispo- } \\
\text { sition }\end{array}$ \\
\hline & & &
\end{tabular}

\begin{tabular}{|c|}
\hline Approval Designator (F) \\
\hline E, S, $Q$, D OR N/A \\
(See WHC-CM-3-5, \\
Sec. 12.7)
\end{tabular}

\begin{tabular}{|l|l|l|}
\hline & 0 & $105 \mathrm{KE}$ \\
\hline & & Area Radiation \\
\hline & & Monitoring System, ARMS \\
\hline & & Procedure, ATP \\
\hline & & \\
\hline
\end{tabular}

Q

KEY

17

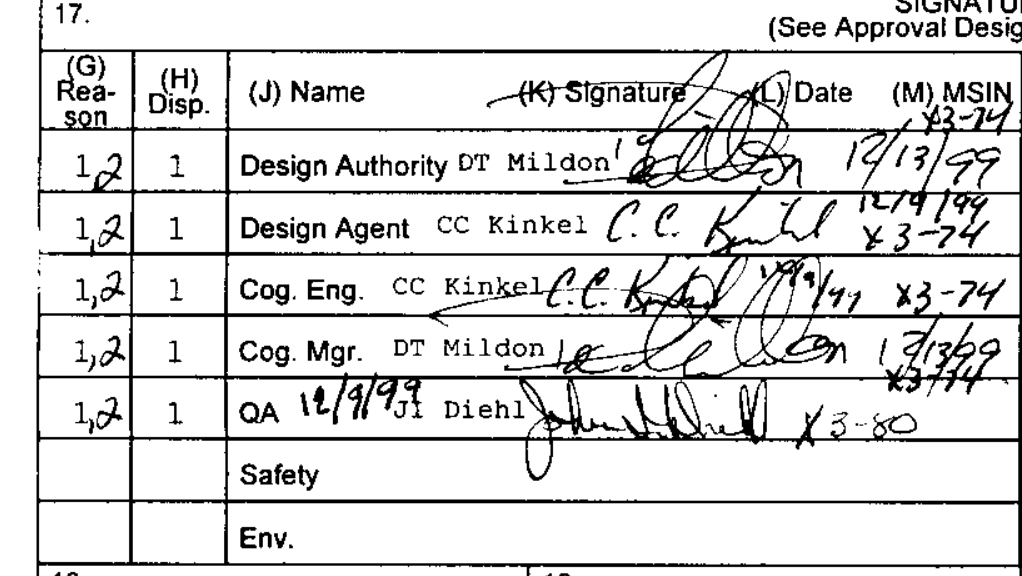

18

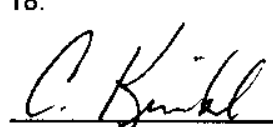

Signature of EDT Originator
$12 / 14 / 44$

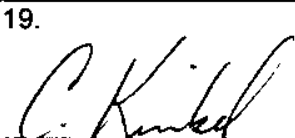

Authorized Representative for Receiving Organization

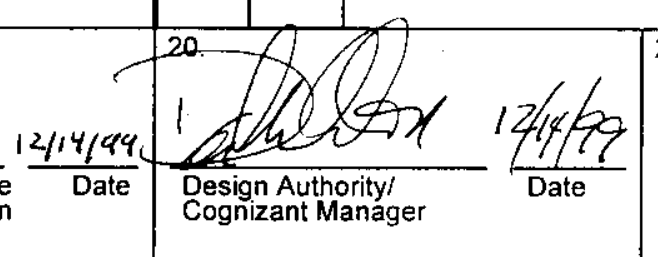

(K) Signature

(L) Date (M) MSIN

1. Approved

2. Approved w/comment

Disposition $(\mathrm{H}) \&(\mathrm{l})$

4. Reviewed no/comment

5. Reviewed w/comment

6. Receipt acknowledged

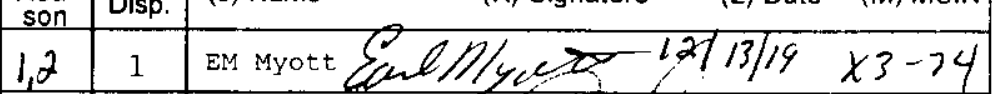
$\begin{array}{llll}1,2 & 1 & \text { FDH/SNFP } & \\ 1 & & \end{array}$ 1,21 PTH/Security EA Koster 171 PTH/Security SE Davis

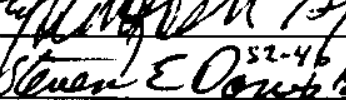




\section{KE BASIN AREA RADIATION MONITOR SYSTEM (ARMS) ACCEPTANCE TEST PROCEDURE}

CC Kinkel

Fluor Daniel Hanford

Richland, WA 99352

U.S. Department of Energy Contract DE-AC06-96RL13200 CCK $12 / 16 / 44$

\author{
EDT/ECN: 626037 \\ Org Code: 2E600 \\ B\&R Code: ${ }^{C K}, 2 / 13199$ \\ EW 3130000
}

Key Words:

UC: 2000

Charge Code: 111458

Total Pages:

$5 \times 58$

cck / fee , 2/4/4?

12114199

ARMS, Radiation Monitor, Data Logger, VGR, Area Radiation Monitor

Abstract:

The attached Acceptance Test Will test the yiow KE Arca Radiation

Monitoring system (ARMS)

TRADEMARK DISCLAIMER. Reference herein to any specific commercial product, process, or service by trade name. trademark, manufacturer, or otherwise, does not necessarily constitute or imply its endorsement, recommendation. or favoring by the United States Government or any agency thereof or its contractors or subcontractors

Printed in the United States of America. To obtain copies of this document, contact: Document Control Services. P.O. Box 950, Mailstop H6-08, Richland WA 99352, Phone (509) 372-2420; Fax (509) 376-4989.
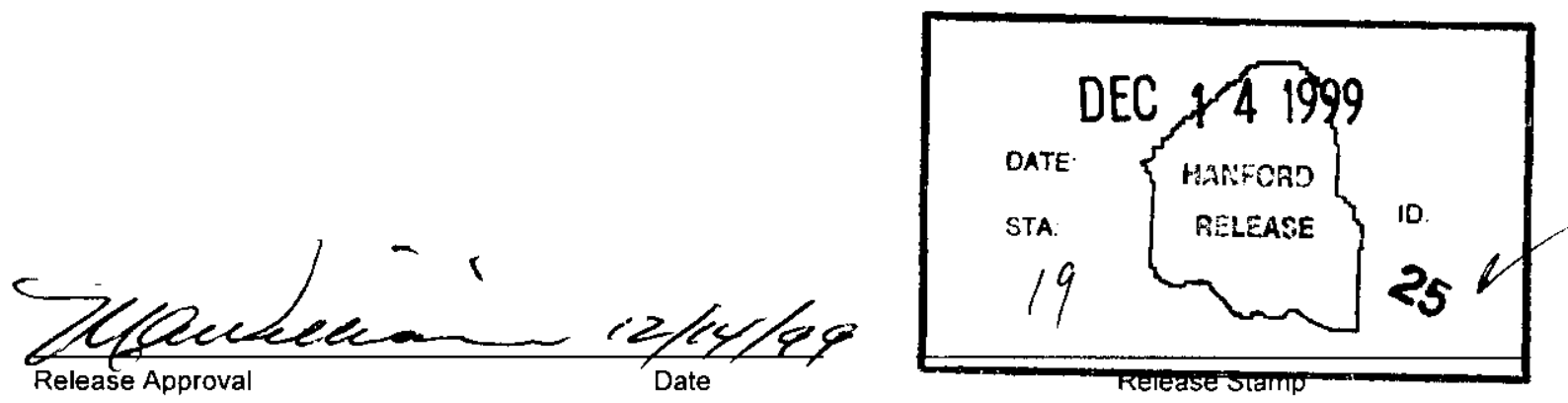

Approved For Public Release 


\section{$105 \mathrm{KE}$}

Area Radiation Monitoring System, ARMS

Acceptance Test Procedure, ATP

HNF-3613, Revision 0

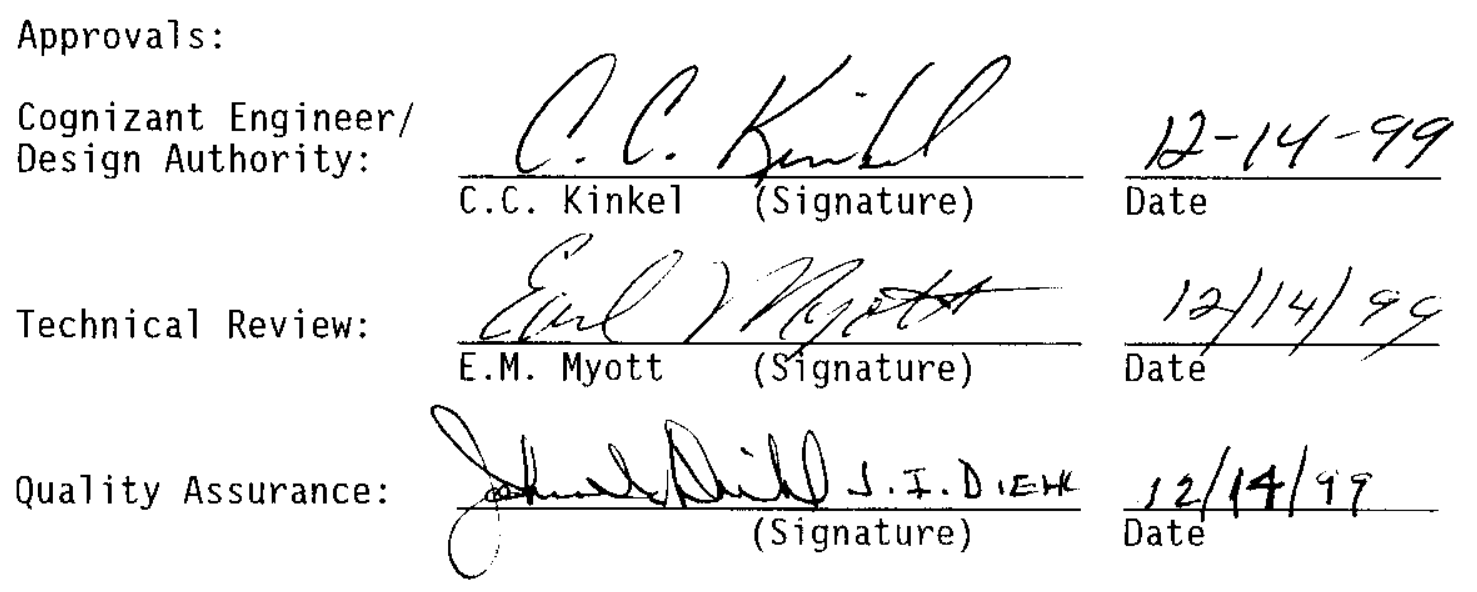


HNF-1363

Revision 0

Page ii of vi

Table of Contents

1.0 Introduction ........................ 1

1.1 Purpose And Scope . . . . . . . . . . . . . . . . . . . . 1

1.2 Acronyms And Abbreviations . . . . . . . . . . . . . . 1

1.3 References .................... 2

1.4 System Equipment Identification ............ 2

1.5 System Block Diagram ............... . . 4

2.0 Test Description ..................... 5

2.1 Objectives .................... . . 5

2.2 Test Method . . . . . . . . . . . . . . . 5

3.0 Test Condition Limits . . . . . . . . . . . . . . . . . . 5

3.1 Equipment Prerequisites................ . 5

3.2 Personnel Prerequisites . . . . . . . . . . . . . . 5

3.3 Responsibilities . . . . . . . . . . . . . . . 7

4.0 Instruments And Calibration ................. 11

4.1 Tools, Equipment, And Materials ............ 11

4.2 Instrument list . . . . . . . . . . . . . . . . . 12

5.0 Test Facility. . . . . . . . . . . . . . . . 13

5.1 Facility ..................... . . . 13

5.2 Equipment And Materials . . . . . . . . . . . . . . . . 13

6.0 Safety .................... . . . 14

7.0 Equipment Failure ................... 14

8.0 Test Data..................... 15

9.0 Personner Requirements ................. 15

10.0 Procedure .................... . . . . 16

10.1 Security Door Tamper Test . . . . . . . . . . . . . . . 16

10.2 Record Equipment Serial Numbers . . . . . . . . . . . . . . 16

10.3 Verify Rack Power And Check Fan Operation . . . . . . . . . . 16

10.4 Calibration And Radiation Alarm Check. . . . . . . . . . . 18

10.5 System Alarm Test . . . . . . . . . . . . . . . . . . . 23

10.6 Watchdog Relay Test . . . . . . . . . . . . . . . . . . 24

10.7 Upscale Check Functionality Test . . . . . . . . . . . . . . 25

10.8 Source Check . . . . . . . . . . . . . . . . . 27

10.9 Password Security Test . . . . . . . . . . . . . . . . 28

10.10 Final ARMS System Check Out . . . . . . . . . . 28

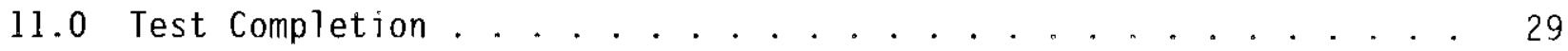

12.0 Data Sheets . . . . . . . . . . . . . . . . . . 30

12.1 Calibration Data Sheets............. . . . 30 
HNF -1363

Revision 0

Page $i i j$ of $v i$

12.2 Radiation Alarm Data Sheets............. . . 35

12.3 System Alarm Data Sheet... . . . . . . . . . . . . . . . . 40

12.4 Watchdog Relay Data Sheet . . . . . . . . . . . . . . . . 42

12.5 Password Security Test Data Sheet... . . . . . . . . . . . 43

13.0 Test Execution Completion Sheet . . . . . . . . . . . . . . . . . . 44

14.0 Test Exception . . . . . . . . . . . . . . . . . . . . . 45 
HNF- 1363

Revision 0

Page iv of $v i$

List of Tables

105KE Equipment... . . . . . . . . . . . . . . . . . . 3

Instrument List . . . . . . . . . . . . . . . . . . . . . . . . . . . . . 12

Calibration Data Sheet - AIM Channel \#1, Detector \#7 . . . . . . . . . . 31

Calibration Data Sheet - AIM Channel \#2, Detector \#8. . . . . . . . . . 31

Calibration Data Sheet - AIM Channel \#3, Detector \#9 . . . . . . . . . . 32

Calibration Data Sheet - AIM Channel \#4, Detector \#10. . . . . . . . . . 32

Calibration Data Sheet - AIM Channel \#5, Detector \#11......... . 33

Calibration Data Sheet - AIM Channel \#6, Detector \#12A . . . . . . . . . . . 33

Calibration Data Sheet - AIM Channel \#7, Detector \#12B . . . . . . . . . 34

Calibration Data Sheet - AIM Channel \#8, Detector \#13. . . . . . . . . . 34

Low Level Radiation \& System Trouble Alarm Check . . . . . . . . . . . . 36

Intermediate Level Radiation Alarm And Upscale Function Check. . . . . . 37

High Level Radiation Alarm Check . . . . . . . . . . . . . . . . . . . . 38

Source Bugging Chambers Alarm Check. . . . . . . . . . . . . . . . . . . 39

System Alarm Data Sheet . . . . . . . . . . . . . . . . . . . . . . . . . 41 
HNF- 1363

Revision 0

Page $v$ of $v i$

\section{List of Figures}

Figure 1. 105KE ARMS Block Diagram. . . . . . . . . . . . . . . . . . . 4 
HNF -1363

Revision 0

Page $v i$ of $v i$

List of Appendices

Appendix A - VGR Alarm Function Table . . . . . . . . . . . . . . . . . . 46

Appendix B - VGR System Alarm Table . . . . . . . . . . . . . . . . . . 48

Appendix C - Equipment Failure Log . . . . . . . . . . . . . . . . . . . 50

Appendix D - 105KE Radiation Detector Data Sheet . . . . . . . . . . . . 51 
HNF -3613

Revision 0

Page 1 of 51

\subsection{Introduction}

\subsection{Purpose And Scope}

This procedure is intended for the Area Radiation Monitoring System, ARMS, that is replacing the existing Programmable InputOutput Processing System, PIOPS, radiation monitoring system in the 105KE basin. The new system will be referred to as the $105 \mathrm{KE}$ ARMS, 105KE Area Radiation Monitoring System. This ATP will ensure calibration integrity of the 105KE radiation detector 1oops. Also, this ATP will test and document the display, printing, alarm output, alarm acknowledgement, upscale check, and security functions. This ATP test is to be performed after completion of the 105KE ARMS installation.

The alarm outputs of the 105KE ARMS will be connected to the basin detector alarms, basin annunciator system, and security Alarm Monitoring System. AMS, located in the 200 area Central Alarm Station (CAS).

Note: Verification of the Video Graphic Recorder, VGR, Data Logger programming configuration has already been performed. See "Acceptance Test Report For New Data Logger Replacement For The PIOPS Radiation Monitoring Equipment", HNF-SD-SNF-ATR022 for details.

Note: 24 hour notice shall be given to security and operations prior to the ATP being performed. All exterior doors to the basin limited area, with the exception of door 100, will remained locked with their intrusion detectors sensors in the secure mode unless prior arrangements have been made with security.

\subsection{Acronyms And Abbreviations}

$\begin{array}{ll}\text { AC } & \text { Alternating Current } \\ \text { ACK } & \text { Acknowledge } \\ \text { AIM } & \text { Analog Input Module } \\ \text { ALM } & \text { Alarm Module } \\ \text { AMS } & \text { Alarm Monitoring System } \\ \text { ARMS } & \text { Area Radiation Monitoring System } \\ \text { CAS } & \text { Central Alarm Station } \\ \text { CRT } & \text { Cathode Ray Tube } \\ \text { DC } & \text { Direct Current } \\ \text { DMM } & \text { Digital Multimeter } \\ \text { DVM } & \text { Digital Voltmeter } \\ \text { EXT } & \text { External } \\ \text { HLA } & \text { High Level Alarm } \\ \text { hr } & \text { Hour } \\ \text { ILA } & \text { Intermediate Level Alarm }\end{array}$


HNF -3613

Revision 0

Page 2 of 51

$\begin{array}{ll}\text { KWD } & \text { Watchdog Relay } \\ \text { LED } & \text { Light Emitting Diode } \\ \text { ma } & \text { Milliamp } \\ \text { mm } & \text { Millimeter } \\ \text { MO } & \text { Magneto Optical } \\ \text { mR } & \text { Millirem } \\ \text { mV } & \text { Millivolt } \\ \text { NC } & \text { Normally Closed } \\ \text { NO } & \text { Normally Open } \\ \text { PC } & \text { Personal Computer } \\ \text { PIOPS } & \text { Programmable Input-Output Processing System } \\ \text { PRMS } & \text { PIOPS Radiation Monitoring System } \\ \text { TSR } & \text { Technical Safety Report } \\ \text { UART } & \text { Universal Asynchronous Receiver Transmitter } \\ \text { UPS } & \text { Uninterruptable Power Supply } \\ \text { VAC } & \text { Volts Alternating Current } \\ \text { VDC } & \text { Volts Direct Current } \\ \text { VGR } & \text { Video Graphic Recorder }\end{array}$

\subsection{References}

The following references are provided as aids that can be used while performing the ATP test. Information contained in these documents describes how to operate the equipment and provides technical system configuration information.

- Video Graphic Recorder Configuration And Technical Information - Area Radiation Monitoring System (ARMS) 100K. HNF-SD-SNF-TI-037.

- Video Graphic Recorder User Manual - Area Radiation Monitoring System (ARMS) 100K, HNF-SD-SNF-TI-004.

- Acceptance Test Report For New Data Logger Replacement For The PIOPS Radiation Monitoring Equipment, HNF-SD-SNF-ATR022 .

\subsection{System Equipment Identification}

The equipment listed in Table 1, 105KE Equipment, is to be used during the ATP test. For a system overview see Figure 1, 105KE ARMS Block Diagram, located in section 1.5, System Block Diagram. 
HNF-3613

Revision 0

Page 3 of 51

Table 1

105KE Equipment

\begin{tabular}{|c|c|c|c|}
\hline Equipment Type & Manufacturer & Model/Part \# & Serial \# \\
\hline $\begin{array}{l}\text { Video Graphic Recorder } \\
\text { (VGR) }\end{array}$ & Angus Electronics & VGR 16 & \\
\hline $\begin{array}{l}\text { Analog Input Module } \\
\text { (AIM) }\end{array}$ & Angus Electronics & $N / A$ & \\
\hline $\begin{array}{l}\text { Alarm Output Module } \\
\text { (ALM) }\end{array}$ & Angus Electronics & $N / A$ & \\
\hline Color Printer & Citizen & GSX-190 & \\
\hline $\begin{array}{l}\text { Relay, Time Delay } \\
\text { (Watchdog, KWD) }\end{array}$ & $\begin{array}{l}\text { Potter \& } \\
\text { Brumfield }\end{array}$ & CNS $-35-76$ & $N / A$ \\
\hline 105KE Basin Detectors & $\begin{array}{l}\text { Facility Hardware } \\
\text { (Existing) }\end{array}$ & $N / A$ & $N / A$ \\
\hline $\begin{array}{l}\text { ARMS Termination } \\
\text { Cabinet }\end{array}$ & $\begin{array}{l}\text { Facility Hardware } \\
\text { (Existing) }\end{array}$ & $N / A$ & $N / A$ \\
\hline Basin Alarm Interface & $\begin{array}{l}\text { Facility Hardware } \\
\text { (Existing) }\end{array}$ & $N / A$ & $N / A$ \\
\hline
\end{tabular}


$\mathrm{HNF}-3613$

Revision 0

Page 4 of 51

\subsection{System Block Diagram}

The following system block diagram shows the 105KE ARMS as it will be when installed in the field. Refer to section 1.2, Acronyms And

Abbreviations, for identification of system components shown in the following system block diagram.

\section{KE Basin}

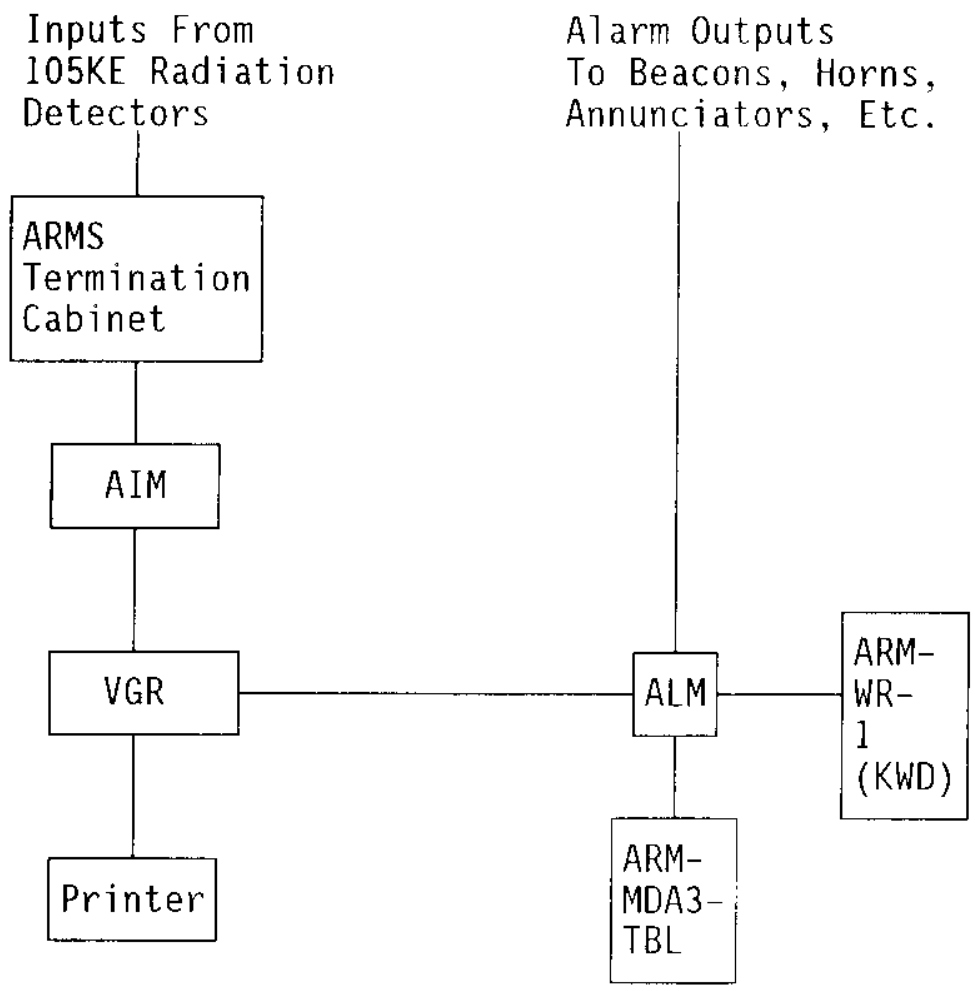

Figure 1. 105KE ARMS Block Diagram. 
HNF -3613

Revision 0

Page 5 of 51

\subsection{Test Description}

\subsection{Objectives}

The ATP test will verify the operation of the equipment identified in Figure 1, 105KE ARMS Block Diagram. 1ocated in section 1.5, System Block Diagram. Specifically, the accuracy and operation of the display, printing, and alarm outputs will be tested and the results documented.

\subsection{Test Method}

The calibration will consist of providing known input signals, 4-19.98 ma corresponding to $1-<100,000 \mathrm{mR} / \mathrm{hr}$, to the selected $V G R$ input channels and observing the VGR, ALM, and printer for proper outputs. The results will be recorded in the spaces provided within this procedure. Also, VGR system failures will be simulated. The VGR system failures will be simulated by turning off the power to a peripheral (printer. ALM, AIM, etc.) and observing the VGR for the proper alarm.

Parts of the ATP test will be run concurrently, such as, verifying basin annunciators and security alarm functions while performing the calibration.

\subsection{Test Condition Limits}

\subsection{Equipment Prerequisites}

Prior to the ATP test, the 105KE ARMS wiring is to be verified to ensure that it is correct before energizing equipment.

\subsection{Personnel Prerequisites}

3.2.1 Operations must be notified before beginning the ATP test and Basin Personnel notified that Radiation Alarms at the Basin will be activated as part of the ATP test.

3.2.1.1 Post signs at the following building locations:

Main entrance South door.

Main entrance North door.

Basin entry door.

D \& D entrance door by HPT counting station. 
HNF -3613

Revision 0

Page 6 of 51

3.2.1.2 Make the following P.A. announcement in $105 \mathrm{KE}$ twice:

"Attention all personnel, Attention all personnel. Radiation monitoring system testing is being performed. Disregard radiation monitoring system annunciators and horns until further notice."

3.2.2 Security Maintenance is to be present during the ATP test and Security at the Central Alarm Station, CAS, are be notified of the ATP test and that radiation alarms will occur as part of the ATP test, but no other security alarms should occur.

3.2.3 Health Physics are to be notified of the ATP test. 
HNF-3613

Revision 0

Page 7 of 51

\subsection{Responsibilities}

3.3.1 Test Director (Cognizant Engineer/Design Authority or Designee)

Test director is responsible for the following:

- Coordinate ATP test activities with Operations, Shift Supervisor, Security, and Health Physics.

- Assign ATP test responsibilities.

- Monitoring the ATP test for compliance with the ATP test procedure.

- Assist with the ATP test prejob briefing.

- Act as liaison between the ATP test participants involved with the ATP test.

- Sign the Test Execution Sheet when the ATP test is approved and accepted.

- Take necessary action(s) to clear exception(s) to the ATP test.

- Sign the ATP Test Exception Sheet(s) when the exception(s) has/have been resolved.

ATP Test Director:

$$
\text { Printed name }
$$

Signature

Date 
HNF -3613

Revision 0

Page 8 of 51

3.3.2 Quality Assurance Representative (QA/QC)

$Q A / Q C$ is responsible for the following:

- Observe the entire ATP test.

- Sign the Test Execution Sheet when the ATP test is approved and accepted.

- Concur with necessary action(s) to clear exception(s) to the ATP test.

- Sign the ATP Test Exception Sheet(s) when the exception(s) has/have been resolved.

- Verify calibration of M \& TE. Ref Table 2.

ATP QA/QC Representative:

Printed name

Signature

$\overline{\text { Date }}$ 
$\mathrm{HNF}-3613$

Revision 0

Page 9 of 51

\subsubsection{Recorder}

Recorder is responsible for the following:

- Record the names of a11 designated personnel on recorder's copy of the ATP prior to the start of the ATP test.

- Observe the entire ATP test and record all ATP test data.

- Mark off every ATP test step on the recorder's copy, next to the step number, after it is completed.

- Record ATP test exceptions, objections, and test steps not performed, on a Test Exception Sheet. Prepare a separate Test Exception Sheet for each exception, objection, etc.. The Test Exception Sheet is located in Section 14, Test Exception Sheet, make copies as needed.

- The final ATP test results are to be submitted to the Cognizant Engineer/Design Authority for approval signatures and distribution.

ATP Recorder:

Printed name

Signature

Date 
HNF -3613

Revision 0

Page 10 of 51

\subsubsection{Training}

It is the intent to have an Operations representative and a Radiological Control representative to be present during the ATP test in order to familiarize themselves with the $105 \mathrm{KE}$ ARMS. It is left to these organizations to determine the level of representation for the ATP test. 
$\mathrm{HNF}-3613$

Revision 0

Page 11 of 51

\subsection{Instruments And Calibration}

4.1 Tools, Equipment, And Materials

4.1.1 A 4-20 ma source is required to perform the ATP test. The 4-20 ma source will simulate the inputs from the 105KE radiation detectors and will be connected to channels 1-8 of the 105KE ARMS. The accuracy of the 4-20 ma source must be at least . $5 \%$. The Transmation model \#1091, or equivalent, meets the requirements of the ATP test.

4.1.2 A timer or stop watch.

4.1.3 A V-Block source, Cobalt 60 with greater than $50 \mathrm{mR} / \mathrm{hr}$. This can be obtained from K-Basins Radiological Control. 
$H N F-3613$

Revision 0

Page 12 of 51

\subsection{Instrument List}

Record all instruments used during the ATP test in Table 2, Instrument List, shown below. Add additional sheets if more space is required.

Table 2

Instrument List

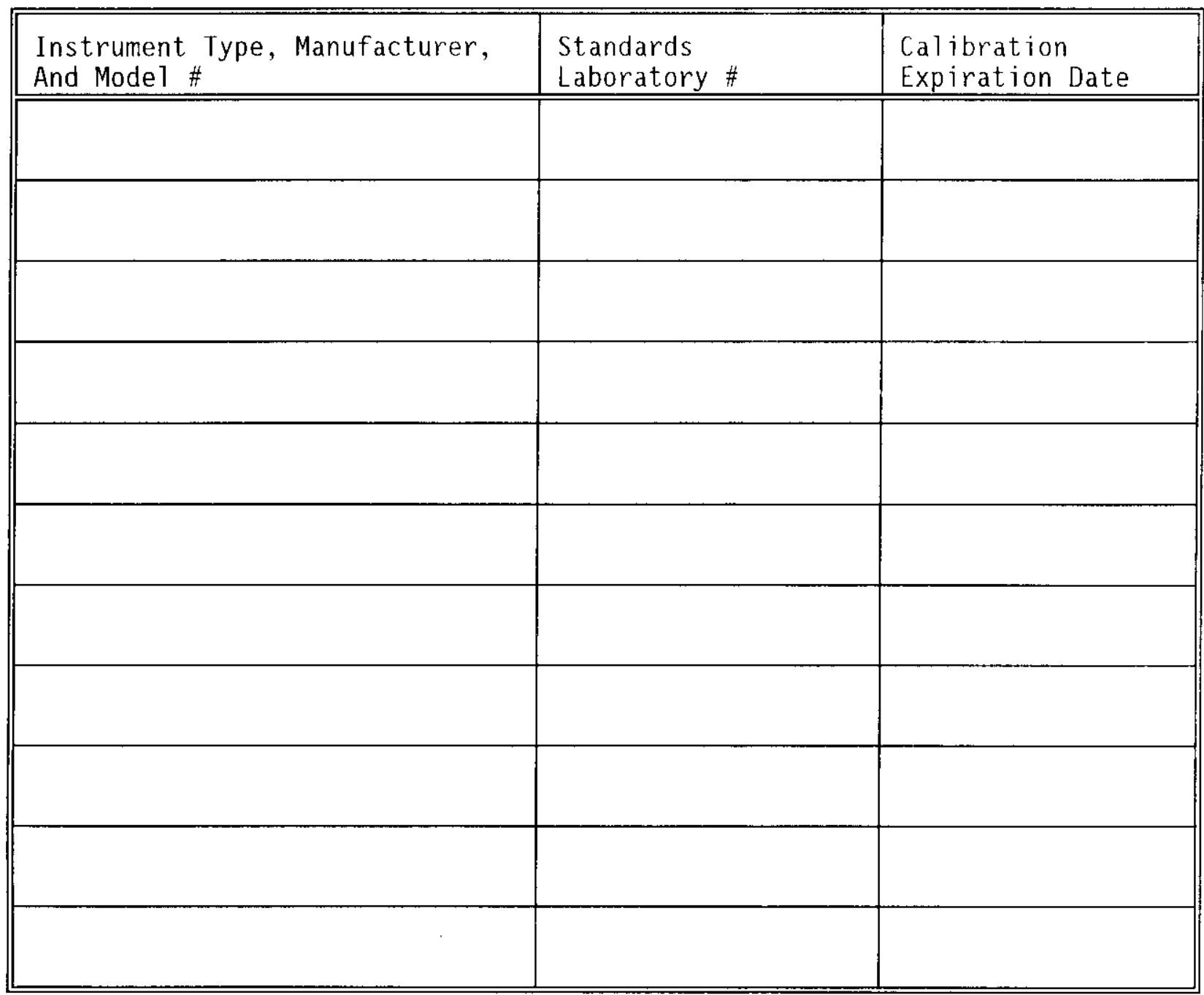


HNF -3613

Revision 0

Page 13 of 51

\subsection{Test Facility}

5.1 Facility

The ATP test will be performed at 105KE Basin. The VGR system is located in 105KE, Room 4.

\subsection{Equipment And Materials}

The equipment to be tested is listed in Table 1, 105KE Equipment, located in section 1.4, System Equipment Identification. Also, the Angus Electronics - VGR Operating Instruction Manual and Citizen Printer - User Manual are to be available for reference, if needed during the ATP test.

A $10 \mathrm{ohm}, \pm .05 \%$, precision resistor is installed across the input terminals of each $105 \mathrm{KE}$ radiation detector input, channels $1-8$. The instruments 1 isted Table 2, Instrument List, located in section 4.2, Instrument List, are needed to perform the ATP test. The 4-20 ma output of the 105KE radiation detectors will be simulated by the 4-20 ma source listed in Table 2, Instrument List, located in section 4.2 , Instrument List. The 4-20 ma signal will be connected to the field termination input terminals located in the KE ARMS Termination Cabinet. The 4-20 ma signal will produce a 40-200 mv signal across the $10 \mathrm{ohm}$ precision resistor into the VGR system.

A 3.5" floppy disk and MO disk for the VGR system must be available. The printer for the VGR system must have an adequate supply of paper and a replacement printer ribbon. Refer to the manufacturers documentation for installation instructions for each of these items.

The Alarm Module, ALM, relay outputs have no visual indicators on them. The Low, Intermediate, High, and selected system trouble alarm functions will be verified for each detector by observing the action of the 105KE ARMS beacons, lights, and horns. All alarm outputs use the normally closed, NC, relay output contact, except the VGR Reset, watchdog, output \#24, Low/System Trouble Alarm To Security output \#26, and Intermediate Alarm To Security output \#27, which use the normally open, N0, relay output contact.

The watchdog relay, KWD, 1 isted in Table 1, 105KE Equipment, located in section 1.4, System Equipment Identification, must be correctly wired and programmed. The watchdog circuit monitors the operation of the VGR system and activates an alarm on the basin annunciator control panel CP-A in room 7 if the VGR system locks up and can no longer scan the $105 \mathrm{KE}$ radiation detector outputs. The KWD relay has an adjustable time delay-on-release feature. The time delay knob on the KWD relay is set to seven to fifteen 
(7-15) seconds. The KWD relay is maintained in an energized, nonalarm, state by periodic pulses from the VGR system. ALM. The reset pulses occur approximately every seven to fifteen seconds and reset the internal timer in the KWD relay. The KWD relay wi]l de-energize in approximately seven to fifteen seconds if the VGR system stops sending the reset pulses to the KWD relay, causing a Low Level Radiation \& System Trouble Alarm. The KWD relay contacts are wired in parallel with the Low Alarm \& System Trouble relay output \#40 of the ALM. This is done so that either the VGR system or the KWD relay can trigger an basin annunciator alarm.

\subsection{Safety}

6.1 Do not apply more than 100 volts DC, or peak $A C$, to the VGR inputs as this may cause damage to the equipment.

6.2 The KE Arms Termination Cabinet contains energized 120 VAC circuits. Extreme care is needed in removing wiring during the ATP test in order to prevent electrical shorts.

6.3 All basin personnel must be informed that the ATP test is in progress and that alarms will be activated, but they are not to respond unless directed otherwise.

\subsection{Equipment Failure}

The following identifies equipment failures that may occur and what action to take. The Cognizant Engineer/Design Authority will be the authority for restarting the ATP test after equipment failure. Record equipment failures in Appendix C, Equipment Failure Log.

\subsection{Power Failure}

After power is restored, observe equipment during power-up for any errors. If no errors occur, continue the ATP test from point of power failure.

\subsection{Disk Failure}

If the 3.5" floppy disk or MO disk fail, replace failed disk using the procedure in the Angus Electronic:s - VGR Operating Instruction Manual and continue the ATP test.

\subsection{Printer Failure}

If the printer fails, troubleshoot using the manufacturers manual. Problems like paper jams and ribbon failures can be cleared and the ATP test continued. If the printer fails completely replace it and continue the ATP test. 
HNF-3613

Revision 0

Page 15 of 51

\subsection{AIM Failure}

If the AIM fails, or does not pass calibration check, replace it with another AIM, perform section 10 calibration check, and continue the ATP test. If the AIM fails section 10 calibration check perform manufacturers calibration procedure listed in Angus Electronics - VGR Operating Instruction Manual and then perform section 10 calibration check.

\subsection{VGR Failure}

If the VGR fails replace it with another VGR. Configure the VGR like the failed unit using the instructions in the Angus

Electronics - VGR Operating Instruction Manual. Continue the ATP test from where it was stopped.

\subsection{Cable Failure}

Replace the failed cable and continue the ATP test from the point of failure.

\subsection{Test Data}

The data to be gathered for the ATP test will be a combination of calibration and alarm function data. The data will be recorded on the data sheets in section 12.0, Data Sheets. The data will be displayed on the VGR screen and printer output. The data has no security classification and will be reported in Acceptance Test Report, ATR, HNF3614 , after completion of the ATP test.

\subsection{Personnel Requirements}

The ATP test will be performed by an Instrument Technician and the Cognizant Engineer/Design Authority. The Cognizant Engineer/Design Authority and a representative from $Q A / Q C$ will observe the entire ATP test. Security personnel at the CAS will verify receipt of alarms as part of the ATP test. Representatives from Operations and Health Physics may be present to familiarize themselves with the KE ARMS.

The basin shall be manned and open with two person rule requirements met. Any individual who is in the RBA must have a 2 security clearance or be accompanied by an authorized escort. 
HNF -3613

Revision 0

Page 16 of 51

\subsection{Procedure}

Insure the VGR system is configured as described in section 5.0 , Test Facility. Also, insure that all equipment and documentation 1 isted in section 5.0, Test Facility, is available before proceeding.

\subsection{Security Door Tamper Test}

10.1.1 Verify with CAS that the ARMS rack cabinet door and the ARMS termination cabinet door are in the secure mode and the alarms are cleared.

10.1.2 Open the ARMS rack rear cabinet door and verify that the alarm has occurred at CAS.

10.1.3 Open the ARMS termination cabinet door and verify that the alarm has occurred at CAS.

10.1.4 In the ARMS termination cabinet. turn on the MDA3 power switch.

10.2 Record Equipment Serial Numbers

10.2.1 Record the VGR serial number in Table 1, 105KE Equipment, located in section 1.4, System Equipment Identification.

10.2.2 Record the AIM serial number in Table 1, 105KE Equipment, located in section 1.4, System Equipment Identification.

10.2.3 Record the ALM serial number in Table 1, 105KE Equipment, Tocated in section 1.4, System Equipment Identification.

10.2.4 Record the printer serial number in Table 1. 105KE Equipment, located in section 1.4, System Equipment Identification.

\subsection{Verify Rack Power And Check Fan Operation}

10.3.1 Ensure that the KE ARMS Rack is supplied with power from the 105KE uninterruptable power supply. UPS, located in $105 \mathrm{KE}$, Room 3.

Completed OK

$\frac{1}{\text { Initials / Date }}$


HNF -3613

Revision 0

Page 17 of 51

10.3.2 Ensure that the KE Arms Rack temperature control circuit breaker is energized.

Completed OK

$\frac{1}{\text { Initials / Date }}$

10.3.3 Verify the KE Arms Rack fan operation by increasing, then decreasing the temperature control located in the KE ARMS Rack and observing that the fan turns on with decreased setting and turns off with increased setting.

Completed OK $\frac{1}{\text { Initials / Date }}$ 
HNF -3613

Revision 0

Page 18 of 51

\subsection{Calibration And Radiation Alarm Check}

The following steps outline the method for concurrently checking the calibration of an analog input channel and testing the radiation alarms. Also, the Low Level Radiation \& System Trouble Alarm will be verified when the field wires of a $105 \mathrm{KE}$ radiation detector are disconnected to connect the simulated 4-20 ma signal. One channel will be checked/tested at a time by inputting a simulated 4-20 ma signal at the $105 \mathrm{KE}$ radiation detector input terminals located in the KE ARMS Termination Cabinet. The other channels will remain connected to their respective detectors. As each channel is checked/tested the results will be recorded on a data sheet located in section 12, Data Sheets.

The annunciation of the Low Level Radiation \& System Trouble Alarm, and the Intermediate Level Radiation Alarm, both sent to CAS will be verified by personnel at these facilities during the calibration of the first detector. CAS will then be notified that subsequent alarms will not be verified.

Note: If the low level setpoint cannot be set low enough to turn off alarms, then the artificial background switch in the 105KE radiation detector will need to be activated. Change the VGR math channel configuration for the $105 \mathrm{KE}$ radiation detector setpoint as identified in the manual. Videographic Recorder Configuration And Technical Information - Area Radiation Monitoring System (ARMS) 100K, HNF-SD-SNFTI-037, Appendix D, Alarm Setpoint Table.

10.4.1 Place the 3.5" floppy boot disk and MO disk into their respective drives and apply power to the KE ARMS.

Note: $\quad$ The VGR firmware revision numbers will only be on the screen for a short time. Be prepared to record the firmware revision numbers.

10.4.2 During the boot-up process the VGR will display it's firmware revision levels. Record Program Version and ROM Loader Version revision numbers in section 12.1 . Calibration Data Sheets.

10.4.3 Record the AIM serial number above Tables 3 through 10. Calibration Data Sheets, located in section 12.0. Data Sheets.

10.4.4 Record the ALM serial number above Table 11, Radiation Alarm Data Sheet - Low Level Radiation \& System Trouble Alarm Check. Tocated in section 12.2 . Radiation Alarm Data Sheet.s. 
HNF -3613

Revision 0

Page 19 of 51

10.4.5 After a successful power-up of the VGR system press the PAGE button on the VGR front panel. Using the up or down arrows, highlight page 5 and press the PAGE button again. Record the VGR revision number in section 12.1, Calibration Data Sheets. Press the PAGE button again, highlight page 1 using the up or down arrows then press PAGE button again to return to the original screen.

10.4.6 Acknowledge all ARMS alarms and have operations at both 105 control panels $C P-A$ take any radiation alarms for 105KE out of bypass and verify that all $105 \mathrm{KE}$ radiation alarms are cleared.

10.4.7 Verify at CAS that the low/system trouble and intermediate radiation aliarms are in the secure mode and are cleared.

Warning: $\quad 24$ VDC power is on, creating a potential shock hazard. Be careful not to contact wiring with any unspecified points.

10.4.8 For each 105KE radiation detector under test, disconnect the field positive input wire at the appropriate terminal block in the KE Arms Termination Cabinet prior to testing. Be careful not to short the wire to any other object.

10.4.9 Perform a Low Level Radialion \& System Trouble Alarm verification when removing one of the $105 \mathrm{KE}$ radiation detector field wires and record result in Table 11 , Radiation Alarm Data Sheet - Low Level Radiation \& System Trouble Alarm Check located in section 12.2, Radiation Alarm Data Sheets.

10.4.9.1 Verify for the 105KE radiation detector a Low Radiation Alarm at $105 \mathrm{KE}$ Basin Control Panel CPA. Verify at CAS that a low/system trouble alarm has occurred. Verify that at the $105 \mathrm{KW}$ Basin Control Panel CP-A that a KE Hi Radiation Alarm has occurred. Record the results in Table 11, Radiation Alarm Data Sheet - Low Level Radiation \& System Trouble Alarm Check located in section 12.2, Radiation Alarm Data Sheets.

Note: $\quad$ Further acknowledgement of the alarm annunciation at remote facilities for the remaining detectors will not be necessary as 
HNF -3613

Revision 0

Page 20 of 51

this verification verifies the rest due to the VGR programming configuration (i.e. if a Low Level Radiation \& System Trouble Alarm for one $105 \mathrm{KE}$ radiation detector works then the rest will work).

10.4.9.2 Verify the remaining Alarm Function Activations listed in Table 11, Radiation Alarm Data Sheet Low Level Radiation \& System Trouble Alarm Check, located in section 12.2, Radiation Alarm Data Sheets. Record results in Table 11 , Radiation Alarm Data Sheet - Low Level Radiation \& System Trouble Alarm Check, located in section 12.2, Radiation Alarm Data Sheets.

10.4.9.3 Notify Security that further alarming will occur and no verification will be necessary until the Intermediate Radiation Alarm check.

10.4.10 Connect the 4-20 ma signal source to an AIM channel, detectors 7-13, of the VGR system. Adjust to a nonalarm value of $6.25 \mathrm{ma}$ (approx. $5 \mathrm{mr}$ ).

Note: Acknowledge the Low Level Radiation \& System Trouble A1arms by pressing the ALARM ACKNOWLEDGE and up/down arrow buttons on the front panel.

10.4.11 Ensure that the remaining channels are not in an alarm state and there is no System Trouble Alarm.

10.4.12 Verify that a channel Low Level Alarm is activated when the simulated signal is decreased below the low level setpoint (2mr/4.96ma). Record results in Table 11, Radiation Alarm Data Sheet - Low Level Radiation \& System Trouble Alarm Check, located in section 12.2, Radiation Alarm Data Sheets. Adjust to a non-alarm value of $6.25 \mathrm{ma}$ (approx. $5 \mathrm{mr}$ ). Acknowledge the Low Level Radiation \& System Trouble Alarms by pressing the ALARM ACKNOWLEDGE and up/down arrow buttons on the front panel.

10.4.13 Verify that the System Trouble Alarm is activated when the VGR is shut off via the power switch located on front of the VGR monitor. Record the result in Table 11, Radiation Alarm Data Sheet - Low Level Radiation \& System Trouble Alarm Check, located in section 12.2, Radiation Alarm Data Sheets.

10.4.14 Reboot the VGR system. 
HNF-36l3

Revision 0

Page 21 of 51

10.4.15 Perform the calibration checks and radiation alarm verification, concurrently. Apply the signals identified in Tables 3 through 10, Calibration Data Sheets, located in section 12.0, Data Sheets. Record the results in Tables 3 through 10, Calibration Data Sheets, located in section 12.0, Data Sheets. Sign and date below Tables 3 through 10, Calibration Data Sheets, when completed. Record any exception(s) on a Test Exception Sheet, located in section 14.0, Test Exception Sheet.

10.4.16 While performing the calibration check on a particular channel, proceed to Table 12, Radiation Alarm Data Sheet - Intermediate Alarm And Upscale Function Check, and Table 13, Radiation Alarm Data Sheet - High Alarm Check, both located in section 12.2, Radiation Alarm Data Sheets, and complete at the same time. As the simulated 4-20 ma signal of a $105 \mathrm{KE}$ radiation detector is increased above the Intermediate Radiation Level Alarm (9.44ma/50mr) and High Radiation Level Alarm (10.4ma/100mr) setpoints, record required data in Table 12, Radiation Alarm Data Sheet - Intermediate Alarm And Upscale Function Check, and Tabie 13, Radiation Alarm Data Sheet. - High Alarm Check. respectively. Sign and date below Tables 12 and 13 when completed. Record any exception(s) on a Test Exception Sheet, located in section 14.0, Test Exception Sheet.

10.4.16.1 Verify a 105KE radiation detector Intermediate Radiation Alarm at the following locations: 1) 105 KE Basin Control Panel, 2) Alarm to Security at CAS. Verify at $105 \mathrm{KW}$ that a $105 \mathrm{KE} \mathrm{Hi}$ radiation $A l \mathrm{arm}$ has occurred. Record results in Table 12, Radiation Alarm Data Sheet Intermediate Alarm And Upscale Function Check, located in section 12.2, Radiation Alarm Data Sheets.

Note: $\quad$ Further acknowledgement for the remaining detectors will not be necessary as this verification verifies the rest due to the VGR programming configuration (i.e. if an Intermediate Level Radiation Alarm for one $105 \mathrm{KE}$ radiation detector works then the rest will work).

10.4.16.2 Verify the remaining actions listed in Table 12 , Radiation Alarm Data Sheet - Intermediate Alarm And Upscale Function Check, located in section 
HNF-3613

Revision 0

Page 22 of 51

12.2, Radiation Alarm Data Sheets. Record the results in Table 12 .

Note: $\quad$ The Intermediate Radiation Alarm will be on during testing of the High Radiation Alarm. The output relay for the. Intermediate Radiation Alarm will remain in an alarm state as long as the input signal is above the Intermediate Radiation Alarm set point.

10.4.16.3 Verify a 105KE radiation detector High Radiation Alarm at the following two locations: 1) $105 \mathrm{KE}$ Basin Control Panel. 2) $105 \mathrm{KW}$ Basin Control Pane1. Record results in Table 13, Radiation Alarm Data Sheet - High Alarm Check, located in section 12.2, Radiation Alarm Data Sheets.

Note: $\quad$ Further acknowledgement for the remaining $105 \mathrm{KE}$ radiation detectors will not be necessary as this verification verifies the rest due to the VGR programming configuration (i.e. if a High Level Radiation Alarm for one detector works then the rest will work).

10.4.16.4 Verify the remaining actions listed in Table 13. Radiation Alarm Data Sheet - High Alarm Check. located in section 12.2, Radiation Alarm Data Sheets. Record the results in Table 13 . 
HNF-3613

Revision 0

Page 23 of 51

\subsection{System Alarm Test}

This section tests the alarms relating to the VGR system itself. Not all of the system alarms can be simulated without possibly damaging the VGR system, so only the system alarms that can be simulated will be tested.

10.5.1 Connect all field wires that were removed from the $105 \mathrm{KE}$ radiation detectors. Ensure that all $105 \mathrm{KE}$ radiation detectors are in a non-alarm state.

Note: It will take approximately 2-3 minutes for the system printer alarm to occur after turning the printer off. The other system alarms should occur within a few seconds of the simulated failure.

10.5.2 Perform one of the actions listed in Table 15, System Alarm Data Sheet, located in section 12.3. Record the results in Table 15, System Alarm Data Sheet.

10.5.3 Verify the alarm by viewing the VGR alarm history page. To view the VGR aTarm history page press the VGR PAGE button on the VGR front panel and then select the desired page by using the VGR arrow keys and then pressing the VGR PAGE button again.

10.5.4 Restore the VGR system to original, non-alarm, configuration when finished with the simulated failure.

10.5.5 Repeat steps 10.4.2 through 10.4.4 for the remaining system alarms to be tested.

10.5.6 Sign and date below Table 15, System Alarm Data Sheet, located in section 12.3, System Alarm Data Sheet. Record any exception(s) on a Test Exception Sheet, located in section 14.0, rest Exception Sheet. 
HNF-3613

Revision 0

Page 24 of 51

10.6 Watchdog Relay Test

The watchdog circuit provides an independent alarm relating to the "health" of the VGR system. The Watchdog Relay, KWD, is a time delay relay that actuates an alarm if it does not receive an electrical pulse every 7-15 seconds from the VGR system. As the name implies, KWD watches the VGR system and in the event of a system lock up provides an alarm.

10.6.1 Ensure that system is in a non-alarm condition.

10.6.2 Disconnect the ALM Reset Pulse output from the KWD relay, KWD terminal 7 or from Relay 24 NC terminal. Start the stop watch/timer.

10.6.3 Stop the stop watch/timer when KWD relay trips and record the trip time for the KWD relay on the Watchdog Relay Data Sheet, located in section 12.4, Watchdog Relay Data Sheet.

10.6.4 Sign and date the Watchdory Relay Data Sheet, located in section 12.4, Watchdog Relay Data Sheet.

10.6.5 Verify system alarm at CAS and other functions identified in Table 1l, Radiation Alarm Data Sheet Low Level Radiation \& System Trouble Alarm Check, located in section 12.2, Radiation Alarm Data Sheets. Record results in the Table 11. Sign and date Table 11 .

10.6.6 Connect wire disconnected in step 10.5.2.

10.6.7 Record any exception(s) on a Test Exception Sheet. located in section 14.0, lest Exception Sheet. 
HNF -3613

Revision 0

Page 25 of 51

\subsection{Upscale Check Functionality Test}

This section checks the upscale check function for each $105 \mathrm{KE}$ radiation detector.

10.7.1 Enable upscale check panel by turning the Enable Key Switch to the oN position.

10.7.2 Ensure system is in a non-alarm state.

NOTE: $\quad$ The act of turning on the upscale enable key will generate an alarm that will have to be acknowledged.

10.7.3 For each 105KE radiation detector engage the upscale detector switch and verify that the Intermediate Level Radiation Alarm activates, indicating that the upscale function is operating properly. Record data in Table 12, Radiation Alarm Data Sheet - Intermediate Alarm And Upscale Function Check, located in section 12.2, Radiation Alarm Data Sheets.

For detectors that have been recently changed out per procedure "Change Out PRMS Detector", SP-05-003, and where the procedure could not be completed due to PIOPS replacement activities, record the following on a 105KE Radiation Detector Data Sheet, Tocated in Appendix D.

10.7.3.1 Record 105KE radiation detector number (i.e. RE216-7, RE-216-8, etc.).

10.7.3.2 Record 105KE radiation detector serial number.

10.7.3.3 Record date.

10.7.3.4 Determine next calibration due date by adding one calendar year to the date shown on the 105KE radiation detector calibration sticker. Record the Next Calibration Due Date.

10.7.3.5 Record position of the AB/OFF, automatic background, switch.

Note: The $A B / O F F$ switch should only be in the $A B$ position if background radiation is causing nuisance alarms with the setpoint set at I mR, which is the lowest possible setting. 
HNF-3613

Revision 0

Page 26 of 51

10.7.3.6 Determine the upscale reference value for a detector by initiating an upscale check. Record the As-Left Upscale Reference Value (mR/hr).

10.7.3.7 Initial and date the Detector Data Sheet.

10.7.3.8 Obtain signature and date from the $\mathrm{PM} / \mathrm{S}$ Administrator for the Recall Database verification.

10.7.3.9 Make photocopies of the Detector Data Sheet(s) and send to the Cognizant Engineer/Design Authority.

$\frac{1}{\text { Initials / Date }}$

10.7.3.10 Make photocopies of the Detector Data Sheet(s) and send to the PM/S Administrator so Recall Database can be updated.

$\frac{1}{\text { Initials } / \text { Date }}$

10.7.3.11 Update the KE ARMS database (formerly PIOPS database) with the current data for these detectors.

$\frac{1}{\text { Initials } / \text { Date }}$


HNF -3613

Revision 0

Page 27 of 51

\subsection{Source Check}

10.8.1 Lower the High Level Radiation Alarm set point for each $105 \mathrm{KE}$ radiation detector to $50 \mathrm{mR} / \mathrm{hr}$.

10.8.2 Apply by direct contact the V-Block source to the side of each 105KE radiation detector at approximately 3 inches from the bottom. Record or verify the following in Table 14:

- $\quad \mathrm{mR} / \mathrm{hr}$ listed on VGR CRT.

- $\mathrm{mR} / \mathrm{hr}$ listed on detector panel meter.

- Intermediate Level Radiation ATarm and High Level Radiation Alarm status on VGR CRT.

- Intermediate Level Radiation Alarm and High Level Radiation Alarm control panel annunciators are $0 \mathrm{~N}$ in 105KE, Room 7.

- Audible Intermediate Level Radiation Alarm and High Level Radiation Alarm are activated.

- Intermediate Level Radiation Alarm, amber Tamp, and High Level Radiation Alarm, red lamp, on KE ARMS Rack status panel are ON.

- Intermediate Level Radiation Alarm, amber rotating beacon, outside of building next to main entrance is $O N$.

- 105KE High Level Radiation Alarm control panel annunciator and audible alarm are ON in 105KW, Room 20A.

- The 105KE Intermediate Radiation Alarm at security CAS is ON.

10.8.3 Set High Level Radiation Alarm set point for each channel back to $100 \mathrm{mR} / \mathrm{hr}$, enter " $1+02$ ". 
HNF-3613

Revision 0

Page 28 of 51

10.9 Password Security Test

10.9.1 Security to perform the Password Security Test and record the required information on the Password Security Test Data Sheet, located in section 12.5, Password Security Test Data Sheet.

10.9.2 Security to sign and date the Password Security Test Data Sheet.

10.10 Final ARMS System Check out

10.10.1 Verify the following:

- VGR monitor is updating each of the eight channels approximately once per second.

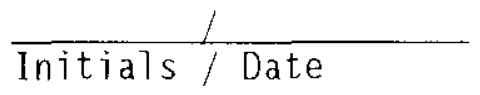

- No channel is reading $00.00+00$ or $01.00+00$ $\mathrm{mR} / \mathrm{hr}$.

$\frac{}{\text { Initials } / \text { Date }}$

- No system error message on the VGR monitor.

$\frac{1}{\text { Initials / Date }}$

10.10.2 Close all cabinet doors. Call security at CAS to secure all 105KE radiation alarms and verify that all alarms are clear.

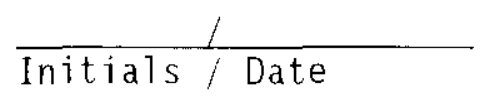


HNF -3613

Revision 0

Page 29 of 51

\subsection{Test Completion}

11.1 Ensure system is operating without any alarms. Ensure the $3.5^{14}$ floppy boot disk is in the disk drive and there is an Mo disk in the Magneto Optica] Drive.

$\frac{1}{\text { Initials / Date }}$

11.2 Ensure calibration sticker is placed on the AIM with a next due date of one year from successful completion date of this ATP test.

$\frac{1}{\text { Initials / Date }}$

11.3 Resolve all test exceptions.

$\frac{1}{\text { Initials / Date }}$

11.4 Sign and date the Test Execution Completion Sheet in section 13.0.

$\frac{1}{\text { Initials / Date }}$


HNF -3613

Revision 0

Page 30 of 51

\subsection{Data Sheets}

12.1 Calibration Data Sheets

The following data sheets document the accuracy of the VGR system Analog Input Module (AIM). The AIM unit is the only piece of equipment in the VGR system that would ever need to be calibrated and is the only component that could be calibrated in the system. The tolerances listed on the following data sheets are the same ones used on the existing system (PRMS). The VGR unit is a display/recording device with serial interfaces to the AIM and ALM units and has no calibration adjustments.

105KE VGR: Program Version \#

ROM Loader Version \#

VGR Revision \# 
$\mathrm{HNF}-3613$

Revision 0

Page 31 of 51

Table 3

Calibration Data Sheet - AIM Channel \#1, Detector \#7

AIM Serial \#

\begin{tabular}{||l|l|l|l|l||}
\hline \hline $\begin{array}{l}\text { Input Value } \\
\text { (ma) }\end{array}$ & $\begin{array}{l}\text { VGR Display } \\
\text { Output (mR/hr) }\end{array}$ & $\begin{array}{l}\text { Tolerance } \\
( \pm 2 \%) \mathrm{mR} / \mathrm{hr}\end{array}$ & $\begin{array}{l}\text { Check If } \\
\text { Cal. In }\end{array}$ & $\begin{array}{l}\text { Check If } \\
\text { Cal. Out }\end{array}$ \\
\hline 4.00 & & $.98-1.02$ & & \\
\hline 7.20 & & $9.8-10.2$ & & \\
\hline 10.40 & & $98-102$ & & \\
\hline 13.60 & & $980-1020$ & & \\
\hline 16.80 & & $9.8 \mathrm{~K}-10.2 \mathrm{~K}$ & & \\
\hline 19.98 & & $98 \mathrm{~K}-102 \mathrm{~K}$ & & \\
\hline
\end{tabular}

Performed by:

Date:

Table 4

Calibration Data Sheet - AIM Channel \#2, Detector \#8

AIM Serial \#

\begin{tabular}{||l|l|l|l|l||}
\hline $\begin{array}{l}\text { Input Value } \\
\text { (ma) }\end{array}$ & $\begin{array}{l}\text { VGR Display } \\
\text { Output (mR/hr) }\end{array}$ & $\begin{array}{l}\text { Tolerance } \\
( \pm 2 \%) \mathrm{mR} / \mathrm{hr}\end{array}$ & $\begin{array}{l}\text { Check If } \\
\text { Cal. In }\end{array}$ & $\begin{array}{l}\text { Check If } \\
\text { Cal. Out }\end{array}$ \\
\hline \hline 4.00 & & $.98-1.02$ & & \\
\hline 7.20 & & $9.8-10.2$ & & \\
\hline 10.40 & & $98-102$ & & \\
\hline 13.60 & & $980-1020$ & & \\
\hline 16.80 & & $9.8 \mathrm{~K}-10.2 \mathrm{~K}$ & & \\
\hline 19.98 & & $98 \mathrm{~K}-102 \mathrm{~K}$ & & \\
\hline \hline
\end{tabular}

Performed by:

Date: 
Table 5

Calibration Data Sheet - AIM Channel \#3, Detector \#9

AIM Serial \#

\begin{tabular}{||l|l|l|l|l||}
\hline $\begin{array}{l}\text { Input Value } \\
\text { (ma) }\end{array}$ & $\begin{array}{l}\text { VGR Display } \\
\text { Output (mR/hr) }\end{array}$ & $\begin{array}{l}\text { Tolerance } \\
( \pm 2 \%) \mathrm{mR} / \mathrm{hr}\end{array}$ & $\begin{array}{l}\text { Check If } \\
\text { Cal. In }\end{array}$ & $\begin{array}{l}\text { Check If } \\
\text { Cal. Out }\end{array}$ \\
\hline 4.00 & & $.98-1.02$ & & \\
\hline 7.20 & & $9.8-10.2$ & & \\
\hline 10.40 & & $98-102$ & & \\
\hline 13.60 & & $980-1020$ & & \\
\hline 16.80 & & $9.8 \mathrm{~K}-10.2 \mathrm{~K}$ & & \\
\hline 19.98 & & $98 \mathrm{~K}-102 \mathrm{~K}$ & & \\
\hline
\end{tabular}

Performed by:

Date:

Table 6

Calibration Data Sheet - AIM Channel \#4, Detector \#10

AIM Serial \#

\begin{tabular}{||l|l|l|l|l||}
\hline $\begin{array}{l}\text { Input Value } \\
\text { (ma) }\end{array}$ & $\begin{array}{l}\text { VGR Display } \\
\text { Output (mR/hr) }\end{array}$ & $\begin{array}{l}\text { Tolerance } \\
( \pm 2 \%) \mathrm{mR} / \mathrm{hr}\end{array}$ & $\begin{array}{l}\text { Check If } \\
\text { Cal. In }\end{array}$ & $\begin{array}{l}\text { Check If } \\
\text { Cal. Out }\end{array}$ \\
\hline 4.00 & & $.98-1.02$ & & \\
\hline 7.20 & & $9.8-10.2$ & & \\
\hline 10.40 & & $98-102$ & & \\
\hline 13.60 & & $980-1020$ & & \\
\hline 16.80 & & $9.8 \mathrm{~K}-10.2 \mathrm{~K}$ & & \\
\hline 19.98 & & $98 \mathrm{~K}-102 \mathrm{~K}$ & & \\
\hline
\end{tabular}

Performed by:

Date: 
HNF-3613

Revision 0

Page 33 of 51

Table 7

Calibration Data Sheet - AIM Channel $\$ 5$, Detector \#11

AIM Serial \#

\begin{tabular}{||l|l|l|l|l||}
\hline $\begin{array}{l}\text { Input Value } \\
\text { (ma) }\end{array}$ & $\begin{array}{l}\text { VGR Display } \\
\text { Output (mR/hr) }\end{array}$ & $\begin{array}{l}\text { Tolerance } \\
( \pm 2 \%) \mathrm{mR} / \mathrm{hr}\end{array}$ & $\begin{array}{l}\text { Check If } \\
\text { Cal. In }\end{array}$ & $\begin{array}{l}\text { Check If } \\
\text { Cal.out }\end{array}$ \\
\hline \hline 4.00 & & $.98-1.02$ & & \\
\hline 7.20 & & $9.8-10.2$ & & \\
\hline 10.40 & & $98-102$ & & \\
\hline 13.60 & & $980-1020$ & & \\
\hline 16.80 & & $9.8 \mathrm{~K}-10.2 \mathrm{~K}$ & & \\
\hline 19.98 & & $98 \mathrm{~K}-102 \mathrm{~K}$ & & \\
\hline
\end{tabular}

Performed by:

Date:

Table 8

Calibration Data Sheet - AIM Channel $\$ 6$, Detector \#12A

AIM Serial \#

\begin{tabular}{||l|l|l|l|l||}
\hline \hline $\begin{array}{l}\text { Input Value } \\
\text { (ma) }\end{array}$ & $\begin{array}{l}\text { VGR Display } \\
\text { Output (mR/hr) }\end{array}$ & $\begin{array}{l}\text { Tolerance } \\
( \pm 2 \%) \mathrm{mR} / \mathrm{hr}\end{array}$ & $\begin{array}{l}\text { Check If } \\
\text { Cal. In }\end{array}$ & $\begin{array}{l}\text { Check If } \\
\text { Cal. Out }\end{array}$ \\
\hline \hline 4.00 & & $.98-1.02$ & & \\
\hline 7.20 & & $9.8-10.2$ & & \\
\hline 10.40 & $98-102$ & & \\
\hline 13.60 & & $980-1020$ & & \\
\hline 16.80 & & $9.8 \mathrm{~K}-10.2 \mathrm{~K}$ & & \\
\hline 19.98 & & $98 \mathrm{~K}-102 \mathrm{~K}$ & & \\
\hline \hline
\end{tabular}

Performed by:

Date: 
HNF -3613

Revision 0

Page 34 of 51

Table 9

Calibration Data Sheet - AIM Channel $\# 7$, Detector \#12B

AIM Serial \#

\begin{tabular}{||l|l|l|l|l||}
\hline $\begin{array}{l}\text { Input Value } \\
\text { (ma) }\end{array}$ & $\begin{array}{l}\text { VGR Display } \\
\text { Output (mR/hr) }\end{array}$ & $\begin{array}{l}\text { Tolerance } \\
( \pm 2 \%) \mathrm{mR} / \mathrm{hr}\end{array}$ & $\begin{array}{l}\text { Check If } \\
\text { Cal. In }\end{array}$ & $\begin{array}{l}\text { Check If } \\
\text { Cal. Out }\end{array}$ \\
\hline \hline 4.00 & & $.98-1.02$ & & \\
\hline 7.20 & & $9.8-10.2$ & & \\
\hline 10.40 & & $98-102$ & & \\
\hline 13.60 & & $980-1020$ & & \\
\hline 16.80 & & $9.8 \mathrm{~K}-10.2 \mathrm{~K}$ & & \\
\hline 19.98 & & $98 \mathrm{~K}-102 \mathrm{~K}$ & & \\
\hline
\end{tabular}

Performed by:

Date:

Table 10

Calibration Data Sheet - AIM Channel \#8, Detector \#13 AIM Serial \#

\begin{tabular}{||l|l|l|l|l||}
\hline $\begin{array}{l}\text { Input Value } \\
\text { (ma) }\end{array}$ & $\begin{array}{l}\text { VGR Display } \\
\text { Output (mR/hr) }\end{array}$ & $\begin{array}{l}\text { Tolerance } \\
( \pm 2 \%) \mathrm{mR} / \mathrm{hr}\end{array}$ & $\begin{array}{l}\text { Check If } \\
\text { Cal. In }\end{array}$ & $\begin{array}{l}\text { Check If } \\
\text { Cal. Out }\end{array}$ \\
\hline \hline 4.00 & & $.98-1.02$ & & \\
\hline 7.20 & & $9.8-10.2$ & & \\
\hline 10.40 & & $98-102$ & & \\
\hline 13.60 & & $980-1020$ & & \\
\hline 16.80 & & $9.8 \mathrm{~K}-10.2 \mathrm{~K}$ & & \\
\hline 19.98 & & $98 \mathrm{~K}-102 \mathrm{~K}$ & & \\
\hline
\end{tabular}

Performed by: Date: 
$H N F-3613$

Revision 0

Page 35 of 51

\subsection{Radiation Alarm Data Sheets}

The following Radiation Alarm Data Sheets cover the three radiation alarms associated with each $105 \mathrm{KE}$ radiation detector. Each of the alarms have output relays that activate such functions as detector beacons, audible annunciators, CRT indication, etc.. The relays will activate when the listed set point is reached for the channel under test. Each alarm will cause an alarm message to appear on both the CRT and printer. The Low Level Radiation \& System Trouble Alarm activates on a descending radiation level. The Intermediate and High Radiation Alarms activate on ascending radiation levels.

All the alarms have either manual or automatic acknowledge, ACK. This means that after the alarm condition clears the alarms with manual ACK will need to be manually acknowledged using the Alarm Acknowledge button on the front of the VGR. The alarms with auto ACK will clear automatically after the alarm condition is removed. 
HNF -3613

Revision 0

Table 11

Radiation Alarm Data Sheet -

Low Level Radiation \& System Trouble Alarm Check

ALM Serial \#

\begin{tabular}{|c|c|c|c|c|c|c|}
\hline \multirow{2}{*}{$\begin{array}{c}\text { Alarm } \\
\text { Function } \\
\text { Activation }\end{array}$} & \multicolumn{6}{|c|}{ Alarm Initiation Event } \\
\hline & $\begin{array}{c}\text { Remove } \\
105 \mathrm{KE} \\
\text { Radiation } \\
\text { Detector Wire } \\
\text { (Any? } \\
\text { Detector) }\end{array}$ & $\begin{array}{c}\text { Remove } \\
\text { Watchdog } \\
\text { Relay (KWD) } \\
\text { Reset PuLse }\end{array}$ & $\begin{array}{c}\text { Low } \\
\text { 105KE } \\
\text { Radiation } \\
\text { Detector } \\
\text { Activity } \\
\text { (Detectors } \\
7-13 \text { ) } \\
\end{array}$ & $\begin{array}{l}\text { Remove } \\
\text { VGR } \\
\text { Power }\end{array}$ & $\begin{array}{l}\text { Check } \\
\text { It } \\
\text { OK }\end{array}$ & $\begin{array}{l}\text { Check } \\
\text { If } \\
\text { Fail }\end{array}$ \\
\hline \multicolumn{7}{|l|}{$\begin{array}{c}\text { KE Arms Rack } \\
\text { Status Panel } \\
\text { Blue Light }\end{array}$} \\
\hline \multicolumn{7}{|l|}{$\begin{array}{c}\text { 105KE Bas in } \\
\text { Control Panet } \\
\end{array}$} \\
\hline \multicolumn{7}{|l|}{$\begin{array}{c}\text { Audible } \\
\text { Annunciator }\end{array}$} \\
\hline \multicolumn{7}{|l|}{$\begin{array}{c}\text { Alarm to } \\
\text { Security at CAS }\end{array}$} \\
\hline \multicolumn{7}{|l|}{$\begin{array}{c}105 \mathrm{KW} \text { Basin } \\
\text { Control Panel }\end{array}$} \\
\hline \multicolumn{7}{|l|}{$\begin{array}{c}\text { KE Arms Rack } \\
\text { Alarm Indicated } \\
\text { on VGR CRT } \\
\end{array}$} \\
\hline $\begin{array}{l}\text { KE Arms Rack } \\
\text { Alarm Printed } \\
\end{array}$ & & & & & & \\
\hline
\end{tabular}

Performed by:

Date:

NOTE: Shaded areas of the above table do not have to be verified 
HNF -3613

Revision 0

Page 37 of 51

Table 12

Radiation Alarm Data Sheet -

Intermediate Level Radiation Alarm And Upscale Function Check

\begin{tabular}{|c|c|c|c|c|c|c|c|c|}
\hline \multirow{2}{*}{ Action } & \multicolumn{8}{|c|}{$\begin{array}{l}\text { ARMS 105KE Radiation Detector } \\
\text { channel No. }\end{array}$} \\
\hline & $\begin{array}{l}7 \\
(1) \\
\end{array}$ & $\begin{array}{r}8 \\
(2) \\
\end{array}$ & $\begin{array}{c}9 \\
(3) \\
\end{array}$ & $\begin{array}{l}10 \\
(4) \\
\end{array}$ & $\begin{array}{l}11 \\
(5) \\
\end{array}$ & $\begin{array}{c}12 \mathrm{~A} \\
(6) \\
\end{array}$ & $\begin{array}{l}12 \mathrm{~B} \\
(7) \\
\end{array}$ & $\begin{array}{l}13 \\
(8) \\
\end{array}$ \\
\hline VGR CRT $(\mathrm{mR} / \mathrm{hr})$ & & & & & & & & \\
\hline Printer (mR/hr) & & & & & & & & \\
\hline $\begin{array}{c}\text { Detector Panel Meter } \\
(\mathrm{mR} / \mathrm{hr})\end{array}$ & & & & & & & & \\
\hline $\begin{array}{c}\text { Intermediate Status } \\
\text { Indication On VGR CRT } \\
(\mathrm{Y} / \mathrm{N}) \\
\end{array}$ & & & & & & & & \\
\hline $\begin{array}{l}\text { 105KE Basin Control } \\
\text { Panel ON }(\mathrm{Y} / \mathrm{N}) \\
\end{array}$ & & & & & & & & \\
\hline $\begin{array}{l}\text { Intermediate Audible } \\
\text { Alarm Activated }(\mathrm{Y} / \mathrm{N})\end{array}$ & & & & & & & & \\
\hline $\begin{array}{c}\text { Intermediate Amber Lamp } \\
0 \mathrm{~N}(\mathrm{Y} / \mathrm{N})\end{array}$ & & & & & & & & \\
\hline $\begin{array}{c}\text { Intermediate Outside } \\
\text { Amber Rotating Beacon ON } \\
(Y / N)\end{array}$ & & & & & & & & \\
\hline $\begin{array}{c}105 \mathrm{KW} \text { Bas in Control } \\
\text { Pane1 ON }(\mathrm{Y} / \mathrm{N}) \\
\end{array}$ & & & & & & & & \\
\hline $\begin{array}{c}\text { Alarm to Security at CAS } \\
\text { ON }(Y / N)\end{array}$ & & & & & & & & \\
\hline Upscale Function Check & & & & & & & & \\
\hline
\end{tabular}

Performed by: Date:

NOTE: Shaded areas of the above table do not have to be verified 
$\mathrm{HNF}-3613$

Revision 0

Page 38 of 51

Table 13

Radiation Alarm Data Sheet -

High Level Radiation Alarm Check

\begin{tabular}{|c|c|c|c|c|c|c|c|c|}
\hline \multirow{2}{*}{ Action } & \multicolumn{8}{|c|}{$\begin{array}{l}\text { ARMS 105KE Radiation Detector } \\
\text { Channel No. }\end{array}$} \\
\hline & $\begin{array}{c}7 \\
(1) \\
\end{array}$ & $\begin{array}{r}8 \\
(2) \\
\end{array}$ & $\begin{array}{c}9 \\
(3) \\
\end{array}$ & $\begin{array}{l}10 \\
(4) \\
\end{array}$ & $\begin{array}{l}11 \\
(5) \\
\end{array}$ & $\begin{array}{l}12 \mathrm{~A} \\
(6) \\
\end{array}$ & $\begin{array}{c}12 \mathrm{~B} \\
(7) \\
\end{array}$ & $\begin{array}{r}13 \\
(8) \\
\end{array}$ \\
\hline \multicolumn{9}{|l|}{ VGR CRT $(\mathrm{mR} / \mathrm{hr})$} \\
\hline \multicolumn{9}{|l|}{ Printer (mR/hr) } \\
\hline \multicolumn{9}{|l|}{$\begin{array}{c}\text { Detector Panel Meter } \\
(\mathrm{mR} / \mathrm{hr})\end{array}$} \\
\hline \multicolumn{9}{|l|}{$\begin{array}{c}\text { High And Intermediate } \\
\text { Status Indication On VGR } \\
\text { CRT }(Y / N)\end{array}$} \\
\hline \multicolumn{9}{|l|}{$\begin{array}{c}\text { 105KE Basin Control } \\
\text { Panel oN }(\mathrm{Y} / \mathrm{N}) \\
\end{array}$} \\
\hline \multicolumn{9}{|l|}{$\begin{array}{c}\text { Intermediate and } \mathrm{Hi} \\
\text { Audible } \mathrm{Alarm} \text { Activated } \\
(\mathrm{Y} / \mathrm{N})\end{array}$} \\
\hline \multicolumn{9}{|l|}{$\begin{array}{c}\text { Intermediate Amber Lamp } \\
\text { and High Red Lamp ON } \\
(Y / N)\end{array}$} \\
\hline \multicolumn{9}{|l|}{$\begin{array}{c}\text { Intermediate Outside } \\
\text { Amber Rotating Beacon ON } \\
(Y / N)\end{array}$} \\
\hline $\begin{array}{c}\text { 105KW Basin Control } \\
\text { Panel ON }(\mathrm{Y} / \mathrm{N})\end{array}$ & & & & & & & & \\
\hline
\end{tabular}

Performed by:

Date:

NOTE: Shaded areas of the above table do not have to be verified 
HNF -3613

Revision 0

Page 39 of 51

Table 14

Radiation Alarm Data Sheet -

Source Bugging Chambers Alarm Check

\begin{tabular}{|c|c|c|c|c|c|c|c|c|}
\hline \multirow{2}{*}{ Action } & \multicolumn{8}{|c|}{$\begin{array}{l}\text { ARMS 105KE Radiation Detector } \\
\text { Channel No. }\end{array}$} \\
\hline & $\begin{array}{c}7 \\
(1) \\
\end{array}$ & $\begin{array}{c}8 \\
(2) \\
\end{array}$ & $\begin{array}{c}9 \\
(3) \\
\end{array}$ & $\begin{array}{l}10 \\
(4) \\
\end{array}$ & $\begin{array}{l}11 \\
(5) \\
\end{array}$ & $\begin{array}{l}12 \mathrm{~A} \\
(6) \\
\end{array}$ & $\begin{array}{l}12 \mathrm{~B} \\
(7) \\
\end{array}$ & $\begin{array}{l}13 \\
(8) \\
\end{array}$ \\
\hline \multicolumn{9}{|l|}{ VGR CRT $(m R / h r)$} \\
\hline \multicolumn{9}{|l|}{$\begin{array}{c}\text { Detector Panel Meter } \\
(\mathrm{mR} / \mathrm{hr})\end{array}$} \\
\hline \multicolumn{9}{|l|}{$\begin{array}{c}\text { High And Intermediate } \\
\text { Status Indication On VGR } \\
\text { CRT }(Y / N) \\
\end{array}$} \\
\hline \multicolumn{9}{|l|}{$\begin{array}{l}\text { High and Intermediate } \\
\text { Annunciator on } \\
\text { Control Panel }(Y / N)\end{array}$} \\
\hline \multicolumn{9}{|l|}{$\begin{array}{r}\text { Intermediate and High } \\
\text { Audible Alarm Activated } \\
(\mathrm{Y} / \mathrm{N}) \\
\end{array}$} \\
\hline \multicolumn{9}{|l|}{$\begin{array}{c}\text { Intermediate Amber Lamp } \\
\text { and High Red Lamp ON } \\
(Y / N)\end{array}$} \\
\hline \multicolumn{9}{|l|}{$\begin{array}{c}\text { Intermediate Outside } \\
\text { Amber Rotating Beacon oN } \\
(Y / N)\end{array}$} \\
\hline \multicolumn{9}{|l|}{$\begin{array}{c}\text { 105KW Basin Annunciator } \\
\text { Panel oN }(\mathrm{Y} / \mathrm{N})\end{array}$} \\
\hline $\begin{array}{l}\text { Alarm to Security at CAS } \\
\text { ON }(Y / N)\end{array}$ & & & & & & & & \\
\hline
\end{tabular}

Performed by:

Date:

NOTE: Shaded areas of the above table do not have to be verified 
HNF -3613

Revision 0

Page 40 of 51

\subsection{System Alarm Data Sheet}

The System Alarm Data Sheet lists the VGR system alarms that can be simulated without damaging the equipment. The following System Alarm Data Sheet also lists the actions necessary to simulate these alarms. Not all of the system alarms can be simulated without possibly damaging the equipment. so not all of them can be tested. All system alarms will appear on the KE Arms Rack print out and on the VGR CRT Alarm page. All the system alarms have a manual ACK to clear the alarm relay output after the alarm condition is cleared. A complete list of the system alarms configured for this system can be found in Appendix B, VGR System Alarm Table. 
HNF-3613

Revision 0

Page 41 of 51

Table 15

System Alarm Data Sheet

\begin{tabular}{||l|l|l|l|l|l|}
\hline $\begin{array}{l}\text { VGR } \\
\text { Channel } \\
\#\end{array}$ & $\begin{array}{l}\text { Alarm } \\
\text { Description }\end{array}$ & $\begin{array}{l}\text { Action To } \\
\text { Simulate Alarm }\end{array}$ & $\begin{array}{l}\text { Print } \\
\text { Out }\end{array}$ & $\begin{array}{l}\text { Check } \\
\text { If Pass }\end{array}$ & $\begin{array}{l}\text { Check } \\
\text { If Fail }\end{array}$ \\
\hline \hline 49 & $\begin{array}{l}\text { No AIM Input } \\
\text { Points }\end{array}$ & $\begin{array}{l}\text { Disconnect Power Cable } \\
\text { To AlM Unit }\end{array}$ & Yes & & \\
\hline 54 & Aim Link Fail & $\begin{array}{l}\text { Disconnect Power Cable } \\
\text { ro AIM Unit }\end{array}$ & Yes & & \\
\hline 55 & $\begin{array}{l}\text { External Alarm } \\
\text { Link Failure }\end{array}$ & $\begin{array}{l}\text { rurn off Power Switch } \\
\text { On ALM Unit }\end{array}$ & Yes & & \\
\hline 57 & Printer Failure & Turn off Printer & No & & \\
\hline
\end{tabular}

Performed by:

Date: 
HNF-3613

Revision 0

Page 42 of 51

\subsection{Watchdog Relay Data Sheet}

The Watchdog Relay Data Sheet in this section provides a space to record the response time of the Watchdog Relay after a simulated system failure.

$$
\text { Watchdog Relay Data Sheet }
$$

Time To Trip: Seconds (Approximately 7-15 Seconds.)

Performed by: Date: 
HNF-3613

Revision 0

Page 43 of 51

12.5 Password Security Test Data Sheet

Password Security Test Data Sheet

105KE ARMS VGR: PASS ___ FAIL_
Performed by: 
HNF -3613

Revision 0

Page 44 of 51

\subsection{Test Execution Completion Sheet}

Al1 steps in section 10.0, Procedure, have been successfully completed and all exceptions, if any, noted in section 14.0, Test Exception Sheet, have been resolved. The KE ARMS is accepted for beneficial use.

Cognizant Engineer/

Design Authority:

$\overline{\text { Signature }} \overline{\text { Date }}$

$Q A / Q C:$

Signature

Date

Operations:

Signature

Date

FDH/SAS :

Signature

Date

PTC/SAS :

Signature

Date 
HNF-3613

Revision 0

Page 45 of 51

\subsection{Test Exception Sheet}

Print the following requested information in the spaces provided, unless otherwise indicated.

Exception Number:

Date:

Name :

Organization:

Phone Number:

Exception:

Planned Action:

Action Taken:

Action Taken Date:

Retest Execution And Acceptance:

Retest approved and accepted.
Excention accepted

as is. Provide details

in the planned action area.
QA/QC Signature

Engineer Signature
Date

Date 


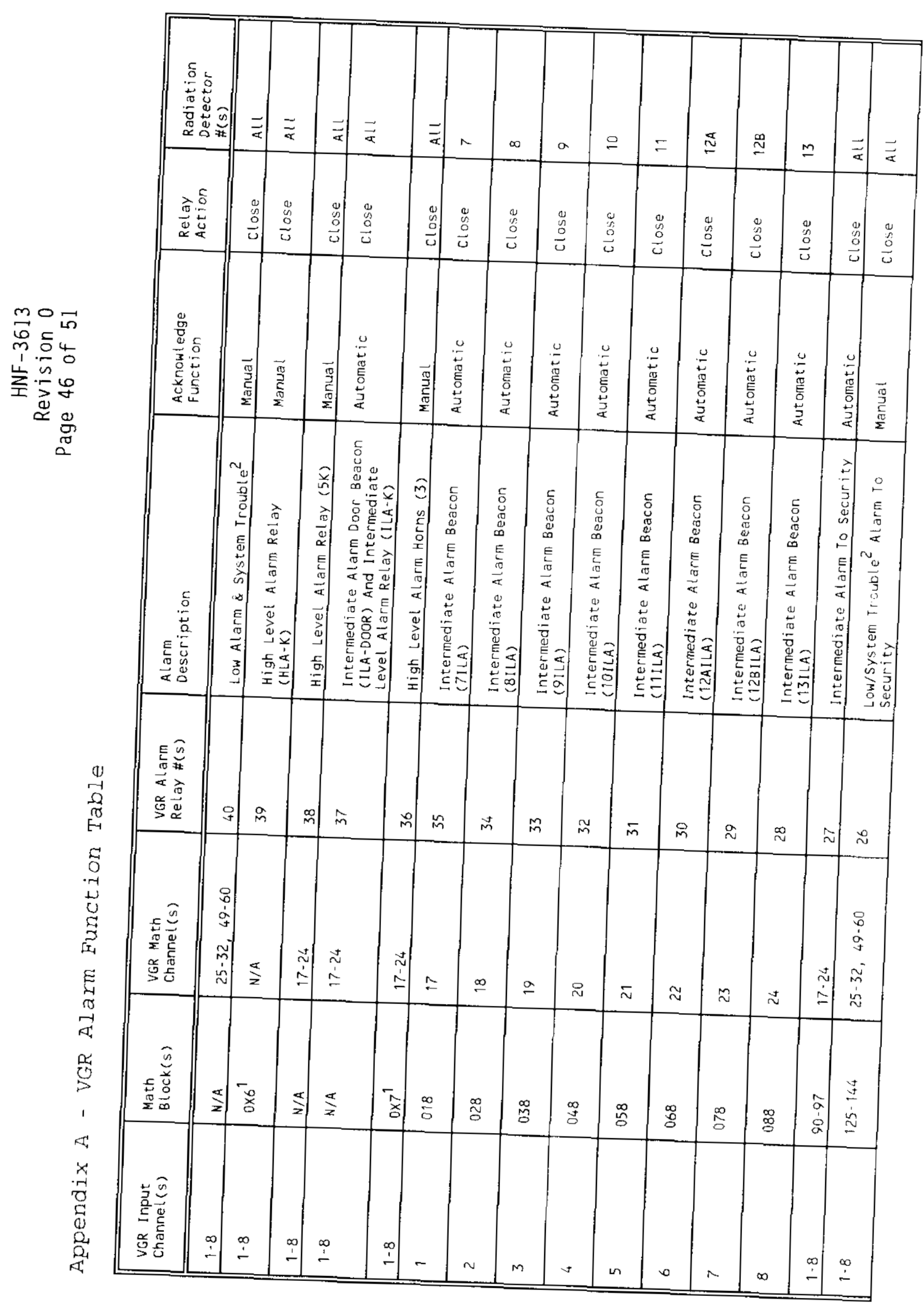




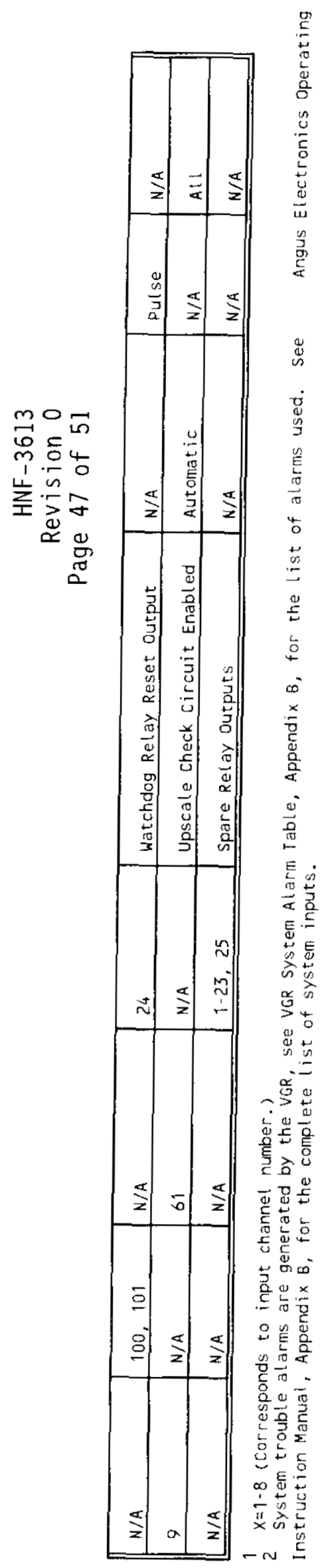


HNF-3613

Revision 0

Page 48 of 51

Appendix B - VGR System Alarm Table

\begin{tabular}{|c|c|c|c|}
\hline $\begin{array}{l}\text { VGR } \\
\text { Channel }\end{array}$ & $\begin{array}{l}\text { System } \\
\text { Number }\end{array}$ & Alarm Type & Alarm Description/Function \\
\hline 1 & $\mathrm{~N} / \mathrm{A}$ & N/A & Open Circuit or Low/High Scale, Detector 7 \\
\hline 2 & N/A & N/A & Open Circuit or Low/High Scale, Detector 8 \\
\hline 3 & N/A & N/A & Open Circuit or Low/High Scale, Detector 9 \\
\hline 4 & $\mathrm{~N} / \mathrm{A}$ & $\mathrm{N} / \mathrm{A}$ & Open Circuit or Low/High Scale, Detector 10 \\
\hline 5 & $\mathrm{~N} / \mathrm{A}$ & N/A & Open Circuit or Low/High Scale, Detector 11 \\
\hline 6 & N/A & N/A & Open Circuit or Low/High Scalc, Detector $12 \mathrm{~A}$ \\
\hline 7 & N/A & $\mathrm{N} / \mathrm{A}$ & Open Circuit or Low/High Scale, Detector $12 \mathrm{~B}$ \\
\hline 8 & $\mathrm{~N} / \mathrm{A}$ & N/A & Open Circuit or Low/High Scale, Detector 13 \\
\hline 9 & $\mathrm{~N} / \mathrm{A}$ & N/A & Upscate Check circuit Enable input \\
\hline 17 & $N / A$ & $\begin{array}{l}\text { Intermediate/ } \\
\text { High Radiation }\end{array}$ & $\begin{array}{l}\text { Intermediate \& High Radiation Alarms Setpoints, } \\
\text { Detector } 7 \text { (Printer Trare Color - Black) }\end{array}$ \\
\hline 18 & $N / A$ & $\begin{array}{l}\text { Intermediate/ High } \\
\text { Radiation }\end{array}$ & $\begin{array}{l}\text { Intermediate \& High Radiation Alarms Setpoints, } \\
\text { Detector } 8 \text { (Printer Trarce Color - Red) }\end{array}$ \\
\hline 19 & $N / A$ & $\begin{array}{l}\text { Intermediate/ } \\
\text { High Radiation }\end{array}$ & $\begin{array}{l}\text { Intermediate \& High Radiation Alarms Setpoints, } \\
\text { Detector } 9 \text { (Printer Trace Color - Blue) }\end{array}$ \\
\hline 20 & N/A & $\begin{array}{l}\text { Intermediate/ } \\
\text { High Radiation }\end{array}$ & $\begin{array}{l}\text { Intermediate \& High Radiation Alarms Setpoints, } \\
\text { Detector } 10 \text { (Printer Trace Color - Yellow) }\end{array}$ \\
\hline 21 & N/A & $\begin{array}{l}\text { Intermediate/ } \\
\text { High Radiation }\end{array}$ & $\begin{array}{l}\text { Intermediate \& High Radiation Alarms Setpoints, } \\
\text { Detector } 11 \text { (Printer Trace Color - Green) }\end{array}$ \\
\hline 22 & N/A & $\begin{array}{l}\text { Intermediate/ } \\
\text { High Radiation }\end{array}$ & $\begin{array}{l}\text { Intermediate \& High Radiation Alarms Setpoints, } \\
\text { Detector 12A (Printer Trace Color - Orange) }\end{array}$ \\
\hline 23 & N/A & $\begin{array}{l}\text { Intermediate/ } \\
\text { High Radiation }\end{array}$ & $\begin{array}{l}\text { Intermediate \& High Radiation Alarins Setpoints, } \\
\text { Detector } 12 B \text { (Printer Trace Color - Purple) }\end{array}$ \\
\hline 24 & $N / A$ & $\begin{array}{l}\text { Intermediate/ } \\
\text { High Radiation }\end{array}$ & $\begin{array}{l}\text { Intermediate o High Radiation Al arms Setpoints, } \\
\text { Detector } 13 \text { (Printer Trace Color - Black) }\end{array}$ \\
\hline 25 & $N / A$ & Low Radiation & $\begin{array}{l}\text { Low Radiation Alarm Setpoint, } \\
\text { Detector } 7\end{array}$ \\
\hline 26 & $N / A$ & Low Radiation & $\begin{array}{l}\text { Low Radiation Alarm Setpoint, } \\
\text { Detector } 8\end{array}$ \\
\hline 27 & N/A & Low Radiation & $\begin{array}{l}\text { Low Radiation Alarn Setpoint, } \\
\text { Detector } 9\end{array}$ \\
\hline 28 & N/A & Low Radiation & $\begin{array}{l}\text { Low Radiation Alarm Setpoint, } \\
\text { Detector } 10\end{array}$ \\
\hline 29 & N/A & Low Radiation & $\begin{array}{l}\text { Low Radiation Alarm Setpoint, } \\
\text { Detector } 11\end{array}$ \\
\hline 30 & $N / A$ & Low Radiation & $\begin{array}{l}\text { Low Radiation Alarm Setpoint, } \\
\text { Detector } 12 \mathrm{~A}\end{array}$ \\
\hline 31 & $N / A$ & Low Radiation & $\begin{array}{l}\text { Low Radiation Alarm Setpoint, } \\
\text { Detector } 12 \mathrm{~B}\end{array}$ \\
\hline
\end{tabular}


HNF -3613

Revision 0

Page 49 of 51

\begin{tabular}{|c|c|c|c|}
\hline 32 & N/A & Low Radiation & $\begin{array}{l}\text { Low Radiation Atarm Setpoint, } \\
\text { Detector } 13\end{array}$ \\
\hline 33 & N/A & Intermediate Radiation & Intermediate Radiation Alarm Print out, Detector 7 \\
\hline 34 & $\mathrm{~N} / \mathrm{A}$ & High Radiation & High Radiation Alarm Print Out, Detector 7 \\
\hline 35 & $\mathrm{~N} / \mathrm{A}$ & Intermediate Radiation & Intermediate Radiation Alarm Print Out, Detector 8 \\
\hline 36 & $\mathrm{~N} / \mathrm{A}$ & $\mathrm{High} \mathrm{Radiation}$ & High Radiation Alarm Print Out, Detector 8 \\
\hline 37 & $N / A$ & Intermediate Radiation & Intermediatc Radiation Alarm Print Out, Detector 9 \\
\hline 38 & $\mathrm{~N} / \mathrm{A}$ & High Radiation & High Radiation Alarm Print out, Detector 9 \\
\hline 39 & N/A & Intermediate Radiation & Intermediate Radiation Alarm Print Out, Detector 10 \\
\hline 40 & N/A & High Radiation & High Radiation Alarm Print Out, Detector 10 \\
\hline 41 & $N / A$ & Intermediate Radiation & Intermediate Radiation Alarm Print Out, Detector 11 \\
\hline 42 & $\mathrm{~N} / \mathrm{A}$ & High Radiation & High Radiation Alarm Print Out, Detector 11 \\
\hline 43 & N/A & Intermediate Radiation & Intermediate Radiation Alarm Print Out, Detector $12 \mathrm{~A}$ \\
\hline 44 & $\mathrm{~N} / \mathrm{A}$ & High Radiation & High Radiation Alarm Print Out, Detector $12 \mathrm{~A}$ \\
\hline 45 & $\mathrm{~N} / \mathrm{A}$ & Intermediate Radiation & Intermediate Radiation Alarm Print Out, Detector 12B \\
\hline 46 & $\mathrm{~N} / \mathrm{A}$ & High Radiation & High Radiation Alarm Print Out, Detector $12 B$ \\
\hline 47 & $N / A$ & Intermediate Radiation & Intermediate Radiation Alarm Print Out, Detector 13 \\
\hline 48 & N/A & High Radiation & High Radiation Alarm Print Out, Detector 13 \\
\hline 49 & $\mathrm{~S} 29$ & System Trouble & No Analog Input Module, AIM, Input Points \\
\hline 50 & $\$ 45$ & System Trouble. & No External Analog Input Module, AIM, Present \\
\hline 51 & 546 & System Trouble & No External Relay \\
\hline 52 & s50 & System Trouble & Analog Input Module, AIM, 1 UART Failure \\
\hline 53 & S52 & System Trouble & External Alarm UART Failure \\
\hline 54 & 556 & System Trouble & Analog Input Module, AIM, 1 Link Failure \\
\hline 55 & 558 & System Trouble & External Alarm Link Failure \\
\hline 56 & 563 & System Irouble & EEPROM ETrOT \\
\hline 57 & S85 & System Trouble & Printer Failure \\
\hline 58 & $\$ 90$ & System Trouble & Disk Error \\
\hline 59 & s91 & System Irouble & Magneto Optical, MO, Di:ik, Full \\
\hline 60 & $\mathrm{~s} 92$ & System Trouble & Magneto Optical, MO, Disk, Error \\
\hline 61 & N/A & Information & Upscale Check Circuit Enabled \\
\hline
\end{tabular}

' See Appendix B of Angus Electronics VGR Manual for the complete list. 
HNF-3613

Revision 0

Page 50 of 51

Appendix C - Equipment Failure Log

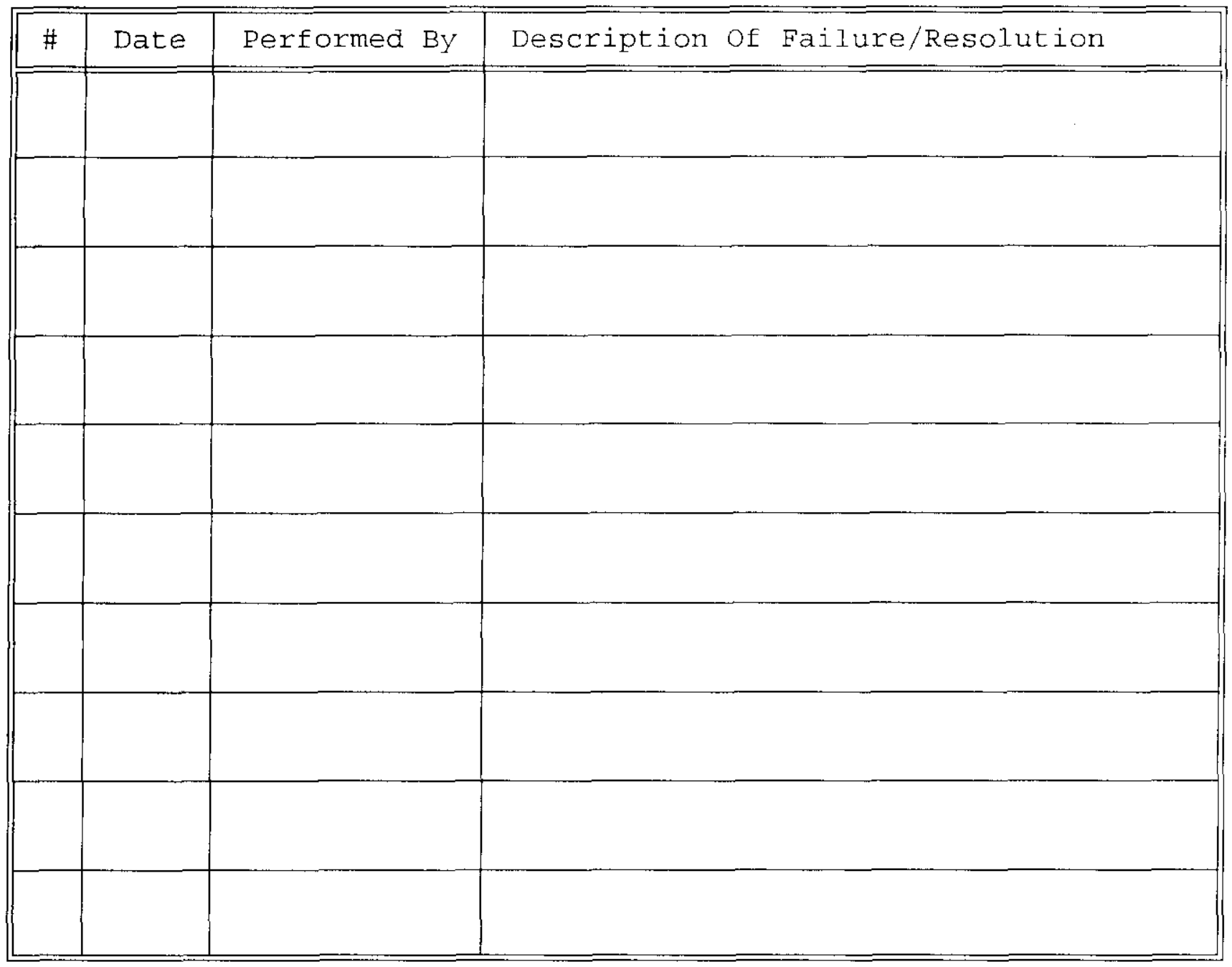


HNF -3613

Revision 0

Page 51 of 51

Appendix D - 105KE Radiation Detector Data Sheet

105KE Radiation Detector Data Sheet

105KE Radiation Detector No. RE-216-

GD-6B 105kE Radiation Detector Serial No.:

Date:

Next Calibration Due Date:

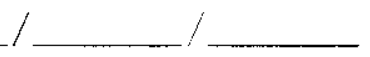

$\mathrm{AB} / \mathrm{OFF}$ Switch Position (Check One): $\mathrm{AB} \longrightarrow \mathrm{OFF}$

As-Left Upscale Reference Value: $\mathrm{mR} / \mathrm{hr}$

Data Recorded By:

$\frac{/}{\text { Initials / Date }}$

Recall Database Verified:

PM/S Administrator

(Signature)

Date 